\title{
AN EMPIRICAL STUDY \\ OF TERRORISM PROSECUTIONS IN CANADA: ELUCIDATING THE ELEMENTS OF THE OFFENCES
}

\author{
MiChAEL NeSBITT $^{*}$ AND DANA HAGG ${ }^{* *}$
}

\begin{abstract}
It has now been over 15 years since Canada enacted the Anti-Terrorism Act, codifying what we think of today as Canada's anti-terrorism criminal laws. The authors set out to canvass how these provisions have been judicially interpreted since their inception through an empirical analysis of court decisions. After exploring how courts have settled initial concerns about these provisions with respect to religious and expressive freedoms, the authors suggest that courts' interpretations of Canada's terrorism offences still leave us with many questions, particularly with respect to the facilitation and financing offences. The authors explore these questions and speculate about future challenges that may or may not be successful with the hopes of providing guidance to prosecutors and defence lawyers working in this area.
\end{abstract}

\section{TABLE OF CONTENTS}

I. INTRODUCTION . . . . . . . . . . . . . . . . . . . . . . 595

II. TERrorism PRoSECUTIONS to DATE . . . . . . . . . . . . . . . . . . . . . . . 599

III. JUDICIAL INTERPRETATIONS OF THE ELEMENTS

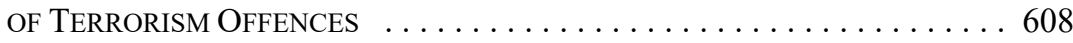

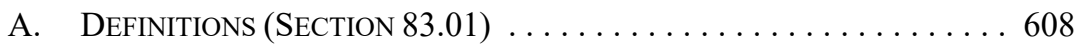

B. OfFEnCES ......................... 620

IV. Conclusions And Future Considerations . . . . . . . . . . . . . 647

\section{INTRODUCTION}

It has now been over 15 years since Canada expeditiously enacted the Anti-Terrorism Act ${ }^{1}$ in the wake of the horrific 11 September 2001 terrorist attacks. The ATA was a watershed moment for criminalizing and prosecuting terrorism in Canada; it enacted Part II.1 of the Criminal Code, ${ }^{2}$ what we think of today as Canada's anti-terrorism criminal laws. ${ }^{3}$ Though

Assistant Professor of Law, University of Calgary, Faculty of Law; Senior Fellow with the Centre for Military, Security and Strategic Studies; Senior Research Affiliate with the Canadian Network for Research on Terrorism, Security and Society (TSAS); and Fellow with the Canadian Global Affairs Institute. The author wishes to thank TSAS for generous funding, without which this research would simply not have been possible. Ian Wylie provided extraordinary research assistance, including profound help putting together the tables of cases and empirical information.

Judicial law clerk at the Court of Queen's Bench of Alberta.

SC 2001, c 41 [ATA].

RSC 1985, c C-46. For a general background on this process, see Craig Forcese, National Security Law: Canadian Practice in International Perspective (Toronto: Irwin Law, 2008) at 261-89 [Forcese, National Security Law].

Prior to 2001, Canada did have section 7(1) and its antecedent, section 5A, which served to criminalize certain terrorist activities like hijacking, which Canada was required to criminalize due to international conventions. Such provisions were actually first added to the Criminal Code under An Act to Amend the Criminal Code, SC 1959, c 41, s 3 . However, prior to 2001, police tended to rely on common Criminal Code provisions in response to terrorist acts. For example, murder charges were laid in multiple cases where today we might think of terrorism offences. See e.g. Lortie c R, [1986] RJQ 2787 (CA); R v Rose, 1973 CanLII 1551(Qc CA); $R$ v Atwal, 1990 CanLII 10930 (BCCA). Moreover, kidnapping charges were laid against members of the Front du Liberation de Québec implicated in the October Crisis: see $R v$ Cossette-Trudel, 1979 CanLII 2876 (Qc CQ). Inderjit Singh Reyat was convicted of manslaughter for his part in the Air India Bombing (see $R v$ Reyat, 2003 BCSC 254). As but another example, Talwinder Singh Parmar was prosecuted for his involvement in the Air India Bombing without invoking section 7 of the Criminal Code, see $R$ v Parmar, 1987 CanLII 6867 (Ont H Ct J). 
Part II. 1 of the Criminal Code has been expanded since $2001,{ }^{4}$ the bulk of Canada's antiterrorism criminal laws date back to the weeks and months just after $9 / 11 .^{5}$

Yet almost a decade later, there was little in the way of judicial interpretation of these criminal provisions. By 2010, the Ontario Court of Appeal was only first expressing its concern that "[n]one of the legislation makes for easy reading." 6 Only two years before, the 2008 Report of the Review of Large and Complex Criminal Case Procedures similarly expressed concern about the novelty and complexity of the terrorism provisions; the report even anticipated that Canada's terrorism laws, as drafted, would contribute significantly to the "mega-trial" phenomenon. ${ }^{7}$ These concerns built on long-standing fears about the complexity of the criminal provisions and the expeditious timeline in which the ATA was passed. For example, the 2004 United Nations Office of Drugs and Crime report described Canada's definition of "terrorist activity" — the backbone of the legislation — as being "impossible to prove."

Those fears were never borne out in practice. Canadian courts simply needed the time to judicially interpret the Criminal Code's Part II.1 provisions in order to give these provisions meaning. In so doing, it became clear that terrorism prosecutions in Canada have been both lengthy and extremely complicated affairs, though the offences have not been impossible to prove. $^{10}$

In 2013, four new provisions were added by the Combating Terrorism Act, SC 2013, c 9 [CTA]: leaving Canada to participate in terrorism - section 83.181 (section 6 of the CTA), leaving Canada to facilitate terrorism - section 83.191(section 7 of the CTA), leaving Canada to commit offence for a terrorist group - section 83.201 (section 8 of the CTA), and leaving Canada to commit terrorist activity section 83.202 (section 8 of the CTA). In 2015, three new provisions were introduced by Bill C-51, An Act to enact the Security of Canada Information Sharing Act and the Secure Air Travel Act, to amend the Criminal Code, the Canadian Security Intelligence Service Act and the Immigration and Refugee Protection Act and to make related and consequential amendments to other Acts, 2nd Sess, 41st Parl, 2015 (assented to 18 June 2015), SC 2015, c 20 [Bill C-51]: advocating terrorism - section 83.221 (section 16 of Bill C-51), warrant of seizure - section 83.222 (section 16 of Bill C-51), and order to computer system's custodian — section 83.223 (sections 16, 35 of Bill C-51).

For an excellent discussion of the continuing relevance of Canada's pre-2001 criminal regime as well as conventional criminal law (murder, sabotage, or inchoate offences such as conspiracy and attempts), see Kent Roach, "The New Terrorism Offences and the Criminal Law" in Ronald J Daniels, Patrick Macklem \& Kent Roach, eds, The Security of Freedom: Essays on Canada's Anti-Terrorism Bill (Toronto: University of Toronto Press, 2002) 151 [Roach, "New Terrorism Offences"].

$6 \quad$ United States of America $v$ Nadarajah, 2010 ONCA 859 at para 13 [Nadarajah ONCA]

Ontario, Ministry of the Attorney General, Report of the Review of Large and Complex Criminal Case Procedures, by the Honourable Patrick J Lesage \& Professor Michael Code (Ontario: MAG, 2008) at 12 [Review of Large and Complex Case Procedures].

$8 \quad$ Criminal Code, supra note 2, s 83.01(1), sub verbo "terrorist activity."

9 UN Office of Drugs and Crime, Legislative Guide to the Universal Anti-Terrorism Conventions and Protocols (New York: UN, 2004) at 10.

10 For example, Momin Khawaja's judge-alone trial took 28 trial days over four months, and the recent jury trial of two suspected extremist travelers spanned over three months. In the Toronto 18 prosecution, the jury trial of three co-accused lasted over nine weeks, and there were at least 30 pre-trial rulings. The tenth pre-trial ruling involved the division of the first count under section 83.18 (participation), as the original indictment had lumped together co-accused who had splintered into new groups due to ideological rifts. The motions judge noted that this difficulty arose from the "interwoven and somewhat complex" nature of Part II.1, which is "written so as to cast a broad net": Rv Ahmad, 2009 CanLII 84772 (Ont Sup Ct J) at para 27. 
As of May 2018, there have been 15 completed terrorism trials in Canada, most of which have been completed since $2010 .{ }^{11}$ There were 19 accused between the 15 trials, of whom five were acquitted and 12 were convicted. ${ }^{12}$ The resulting jurisprudence touches upon most of the Criminal Code's anti-terrorism provisions and indeed addresses many of the longstanding concerns about the complexity and "impossibility" of the Part II.1 provisions. The most important offences have now been adjudicated several times, including at the Supreme Court of Canada. For the first time, we can say that we now have a body of jurisprudence interpreting the mens rea and actus reus for most of the terrorism offences. ${ }^{13}$

In this article, we draw on a comprehensive databank of cases to date with a view to explaining how Canadian courts have defined the predicates of "terrorist activity" and "terrorist group," as well as how courts have given meaning to the "impossible to prove" elements of the criminal offences. The result is the first comprehensive survey of the essential elements (actus reus and mens rea) of the Criminal Code terrorism offences as they have been interpreted by Canadian courts. ${ }^{14}$ It is the authors' hope that the product will be particularly beneficial for prosecutors, defence lawyers, and journalists seeking a consolidated overview of how the courts have treated the various terrorism offences, what issues have been determinatively resolved and are not worth re-litigating, and what legal issues remain open for future consideration.

This article will proceed as follows. In Part II, we provide a brief empirical overview of the terrorism prosecutions in Canada between 2001 when the ATA was first enacted and September 2018. In particular, we outline the number of trials, convictions, judicial

11 For an overview, see Michael Nesbitt, "An Empirical Study of Terrorism Charges and Terrorism Trials in Canada between September 2001 and August 2018" 67:1-2 Crim LQ 95. Twelve trials have been completed since 2010. Of these, eight people were tried individually: Shareef Abdelhaleem, Misbahuddin Ahmed, Ayanle Hassan Ali, Ismaël Habib, Othman Ayed Hamdan, Mohamed Hersi, Khurram Syed Sher, and a Quebec youth. See $R v$ Abdelhaleem, 2011 ONSC 1428 [Abdelhaleem Sentencing]; $R \vee$ Ahmed, 2014 ONSC 6153 [Ahmed Sentencing]; $R$ v Ayanle Hassan Ali, 2018 ONSC 2838 [Ali]; R c Habib, 2017 QCCQ 11427 [Habib Sentencing]; R v Hamdan, 2017 BCSC 1770 [Hamdan Trial]; $R$ v Hersi, 2014 ONSC 4414 [Hersi Sentencing]; $R$ v Sher, 2014 ONSC 4790 [Sher]; LSJPA - 1557, 2015 QCCQ 12938. As well, since 2010, four joint trials were completed: Asad Ansari and Steven Chand, Chiheb Esseghaeir and Raed Jaser, John Nuttall and Amanda Korody, and El Mahdi Jamali and Sabrine Djermane. See $R v$ Esseghaier, 2015 ONSC 5855 [Esseghaier Sentencing]; $R v$ Nuttall, 2016 BCSC 1404 [Nuttall Entrapment Application]; R c Jamali, 2017 QCCS 6078 [Jamali]; "Surprise Guilty Plea in Toronto Terror Trial," CBC News (10 May 2010), online: <cbc.ca/news/canada/ toronto/surprise-guilty-plea-in-toronto-terror-trial-1.891490>.

12 The twelve convicted at trial are Momin Khawaja, Shareef Abdelhaleem, Asad Ansari, Steven Chand, Nishanthan Yogakrishnan, Said Namouh, Raed Jaser, Mohammed Hersi, Misbahuddin Ahmed, Chiheb Esseghaier, Ismaël Habib, and the Quebec youth. See Hersi Sentencing, ibid; Habib Sentencing, ibid; Esseghaier Sentencing, ibid; Ahmed Sentencing, ibid; $R v N Y, 2008$ CanLII 51935 (Ont Sup Ct J) [NY Trial]; LSJPA-1557, ibid; Abdehaleem, ibid; $R$ v Khawaja, 2008 CanLII 92005 (Ont Sup Ct J) [Khawaja ONSC]; John Nuttall and Amanda Korody were also convicted at trial but their convictions were stayed following an entrapment application (see Nuttall Entrapment Application, ibid). The five acquitted are Khurram Sher, El Mahdi Jamali, Sabrine Djermane, Ayanle Hassan Ali, and Othman Ayed Hamdan. See Sher, ibid; Public Prosecution Service of Canada, News Release, "Verdict in Terrorism Case" (19 December 2017), online: <ppsc-sppc.gc.ca/eng/nws-nvs/2017/19_12_17.html>; Ali, ibid; Hamdan Trial, ibid. For more on the number of terrorism prosecutions in Canada since 2001 and their outcomes, see Nesbitt, ibid.

13 Criminal Code, supra note 2, including sections 83.18,83.181,83.19,83.2, and the definitions in section 83.01 .

14 For an excellent early review of Canadian terrorism cases in the context of sentencing, see Robert Diab, "Sentencing for Terrorism Offences: A Comparative Review of Emerging Jurisprudence" (2011) 15:3 Can Crim L Rev 267 [Diab, "Sentencing for Terrorism Offences"]. An excellent initial study of terrorism cases has also been conducted by Kent Roach, though much has transpired - particularly as concerns the interpretation of Criminal Code terrorism offences - since its publication. See Roach, "New Terrorism Offences," supra note 5 at 151. 
decisions, charges, and constitutional challenges to date. We also briefly discuss the geography of the terrorism trials in Canada and what impact that might have had on the jurisprudence to date. In Part III, we draw on this empirical overview of all of the relevant case law in the field in order to elucidate how the courts have interpreted the mens rea and actus reus of each terrorism offence and its predicates, including: how the courts have refined the definitions of "terrorist activity" and "terrorist group" (section 83.01), terrorism financing (sections 83.02-83.04), participation in or contribution to the activity of a terrorist group (section 83.18), leaving Canada to participate in activity of terrorist group (section 83.181), facilitation of terrorist activity (section 83.19), commission of an offence for a terrorist group (section 83.2), and instructing the carrying out of terrorist activity (section 83.22). Finally, we conclude with an overview of the state of the law and some observations on legal issues that are still to be resolved or might arise in the near future, given the trends in terrorism prosecutions in Canada.

Unlike much of the academic writing in this field, this article addresses the substantive criminal requirements of the terrorism provisions, rather than systemic trial issues such as the intelligence-to-evidence problem now well known to those who study national security in Canada, ${ }^{15}$ the related issue of national security privilege claims under section 38 of the Canada Evidence Act, ${ }^{16}$ the mega-trial phenomenon, ${ }^{17}$ the suitability of the criminal law "charge or release" approach to terrorism, ${ }^{18}$ or the sentencing of terrorism offences. ${ }^{19}$ Of course, the approach of this article is limited by the availability of reported decisions, and a number of the more minor terrorism offences are not discussed in this article because they have not yet been adjudicated..$^{20}$

15 Leah West, “The Problem of 'Relevance': Intelligence to Evidence Lessons from UK Terrorism Prosecutions" (2018) 41:4 Man LJ 57; Kent Roach, "The Unique Challenges of Terrorism Prosecutions: Towards a Workable Relation between Intelligence and Evidence," in Commission of Inquiry into the Investigation of the Bombing of Air India Flight 182, vol 4 (Ottawa: Minister of Public Works and Government Services, 2010) [Roach, "Unique Challenges”]; Kent Roach \& Craig Forcese, "Intelligence to Evidence in Civil and Criminal Proceedings: Response to August Consultation Paper" (12 September 2017), online: <ssrn.com/abstract=3035466> [Roach \& Forcese, "Intelligence to Evidence"]. Roach \& Forcese, "Intelligence to Evidence," ibid; Kent Roach, "“Constitutional Chicken': National Security Confidentiality and Terrorism Prosecutions after R. v. Ahmad" (2011) 54 SCLR 357. Review of Large and Complex Case Procedures, supra note 7.

18 Kent Roach, "Be Careful What You Wish For?: Terrorism Prosecutions in Post-9/11 Canada" (2014) 40:1 Queen's LJ 99 [Roach, "Be Careful What You Wish For"].

19 Ibid. See also Diab, "Sentencing for Terrorism Offences," supra note 14; Reem Zaia, "Mental Health Experts in Terrorism Cases: Reclaiming the Status of Rehabilitation as a Sentencing Principle" (2017) 64:3-4 Crim LQ 548 .

20 Sections 83.02 (providing or collecting property for certain activities), 83.04 (using or possessing property for terrorist purposes), 83.191 (leaving Canada to facilitate terrorist activity), 83.201 (leaving Canada to commit offence for terrorist group), 83.202 (leaving Canada to commit offence that is terrorist activity), and 83.221 (advocating or promoting commission of terrorism offences). 


\section{Terrorism Prosecutions to Date}

Part II.1 of the Criminal Code contains 15 criminal terrorism offences, ten that were originally created in 2001 and five more that were added since 2013. ${ }^{21}$ These include:

(1) terrorist financing (sections 83.02-83.04, added 2001);

(2) participating in a terrorist group (section 83.18, added 2001);

(3) leaving Canada to participate in activity of terrorist group (section 83.181, added 2013);

(4) facilitating terrorist activity (section 83.19, added 2001);

(5) leaving Canada to facilitate terrorist activity (section 83.191, added 2013);

(6) commission of offence for terrorist group (section 83.2, added 2001);

(7) leaving Canada to commit offence for terrorist group (section 83.201, added 2013);

(8) leaving Canada to commit offence that is terrorist activity (section 83.202, added 2013);

(9) instructing to carry out activity for terrorist group (section 83.21, added 2001);

(10) instructing to carry out terrorist activity (section 83.22, added 2001);

(11) advocating or promoting commission of terrorism offences (section 83.221, added 2015);

(12) concealing person who carried out terrorist activity (section 83.23(1), added 2001); and

(13) concealing person who is likely to carry out terrorist activity (section 83.23(2), added 2001).

We are aware of 54 individuals ${ }^{22}$ who have been charged with one or more of these terrorism offences under Part II. 1 of the Criminal Code. ${ }^{23}$ Three of the 54 prosecutions are

21 The original terrorism offences were added by the ATA, supra note 1 . The CTA, supra note 4, added four more offences in 2013: leaving Canada to participate in terrorism - section 83.181 (section 6 of the CTA), leaving Canada to facilitate terrorism - section 83.191 (section 7 of the CTA), leaving Canada to commit offence for a terrorist group - section 83.201 (section 8 of the CTA), and leaving Canada to commit terrorist activity - section 83.202 (section 8 of the CTA). In 2015, one more offence was added by Bill C-51: advocating terrorism - section 83.221 .

22 For the full list of those charged with terrorism offences in Canada to date, see Nesbitt, supra note 11, which provides a more robust examination of the trends and outcomes in terrorism prosecutions so far. The total number of prosecutions mentioned here (54) is one short of the total provided by the Public Prosecution Service of Canada in the summer of 2018 (see Public Prosecution Service of Canada, Public Prosecution Service of Canada Annual Report 2017-2018(Ottawa: Attorney General of Canada, 2018), online: <ppsc-sppc.gc.ca/eng/pub/ar-ra/2017 2018/ar18-ra18.pdf > ). The PPSC's total, however, may 
ongoing as of August $2018 .{ }^{24}$ Nine individuals may never appear before a judge since they were charged in absentia (seven of whom have been reported dead). ${ }^{25}$ The table below lists the 42 individuals who have been prosecuted (as contrasted with the 54 that have been charged) to date in Canada. It excludes the 12 individuals who were charged in absentia or whose prosecutions were ongoing as of writing. ${ }^{26}$

\begin{tabular}{|l|l|l|l|}
\hline \multicolumn{1}{|c|}{ Name of Accused } & \multicolumn{1}{c|}{ Style of Cause } & \multicolumn{1}{c|}{ Charges } & \multicolumn{1}{c|}{ Verdict } \\
\hline Shareef Abdelhaleem ${ }^{27}$ & R.v. Abdelhaleem & $\begin{array}{l}83.18 \\
82.2(81(1)(\mathrm{a}))\end{array}$ & $\begin{array}{l}\text { Guilty at trial on all } \\
\text { counts } \\
\text { Sentence: } \text { Life }+5 \text { years } \\
\text { concurrent }\end{array}$ \\
\hline Ibrahim Aboud $^{28}$ & - & 83.18 & Charges stayed \\
\hline
\end{tabular}

count the prosecution of Ali Omar Ader, which was for kidnapping and so is excluded in the total listed here. For a discussion of the total number of individuals charged and issues arising in determining the number of individuals prosecuted for terrorism offences in Canada, see Nesbitt, supra note 11 at 4, n 17.

24 Awso Peshdary, Rehab Dughmosh, and Pamir Hakimzadah. See Evan Dyer, "Trial of Alleged ISIS Recruiter Peshdary Delayed Indefinitely," CBC News (5 March 2018), online: <cbc.ca/news/politics/ peshdary-isis-recruiter-trial-1.4562811>; Paola Loriggio, "Woman Facing Terror Charges in Alleged Canadian Tire Attack Will Stand Trial," CTV News (10 November 2017), online: <toronto.ctvnews. ca/woman-facing-terror-charges-in-alleged-canadian-tire-attack-will-stand-trial-1.3672554>; Shanifa Nasser, "Lawyer for Toronto Man Accused of Travelling to Join ISIS Calls Time Lag on Charges 'Suspect,"” CBC News (6 April 2017), online: <cbc.ca/news/canada/toronto/rcmp-toronto-arrest-1.405 $8007>$

25 The individuals who were charged in absentia are John Maguire, Khadar Khalib, Farah Shirdon, Hasibullah Yusufzai, Ahmad Waseem, Maiwand Yar, Ferid Imam, Mokhtar Belmokhtar, and Omar Hamaha. Yusufzai and Imam are the only two who have yet to be reported deceased. See Stewart Bell \& Meghan Hurley, "Mother Mourns Ottawa Jihadi Maguire, Believed Killed in Syria," The Ottawa Citizen (14 January 2015), online: < ottawacitizen.com/news/national/kemptville-jihadi-maguire-believ ed-killed-in-syria>; Stewart Bell \& Andrew Russell, "Canadian Jihadi Farah Mohamed Shirdon Killed in Iraq Airstrike in 2015: U.S. Military," Global News (7 September 2017), online: <globalnews. ca/news/3722685/canadian-jihadi-farah-mohamed-shirdon-killed-in-iraq-airstrike-in-2015-u-s-military>; Stewart Bell, "Canadian ISIL Fighter Wanted by RCMP May Have Been Killed in Missile Strike in Syria: Document," National Post (19 December 2016), online: <nationalpost.com/news/canada/ canadian-isil-fighter-wanted-by-rcmp-may-have-been-killed-in-missile-strike-in-syria-document $>$; Douglas Quan, "Canadian Jihadist Ahmad Waseem Who Travelled to Syria Likely Killed by Kurdish Forces, Says Researcher," National Post (20 March 2015), online: <nationalpost.com/news/canada/ ahmad-waseem-likely-killed-in-syria>; "RCMP Detail Terrorism Charges Against Two Men," CTV News (15 March 2011), online: <ctvnews.ca/rcmp-detail-terrorism-charges-against-two-men-1.619113>; "Hasibullah Yusufzai: Burnaby Terror Suspect Didn’t Stand Out," CBC News (24 July 2014), online: $<$ cbc.ca/news/canada/british-columbia/hasibullah-yusufzai-burnaby-terror-suspect-didn-t-stand-out1.2717623>. See also "French Strike 'Kills Mali Rebel Commander,"” Al Jazeera (14 March 2014), online:<aljazeera.com/news/africa/2014/03/french-strike-kills-mali-rebel-commander-2014314139427 69651.html>; Simon Usborne, "Dead or Alive? Why the World's Most-Wanted Terrorist Has Been Killed At Least Three Times," The Guardian (28 November 2016), online: <theguardian.com/world/ shortcuts/2016/nov/28/dead-or-alive-mokhtar-belmokhtar-most-wanted-terrorist-killed-three-times>; Joanna Slater \& Colin Freeze, "Letters from a Jihadi: Inside the Mind of a Canadian Accused of Joining al-Qaeda," The Globe and Mail (11 September 2017), online: <theglobeandmail.com/news/world/ letters-from-a-jihadi-canadian-al-qaeda/article36233073/>.

26 For a list of those charged in absentia, see ibid. For those with ongoing prosecutions, see supra note 24.

27 The charges listed for Abdelhaleem, and for all accused whose prosecutions proceeded to trial, are those that the Crown proceeded with at trial. Charges that may have been laid earlier in the prosecution were not counted. For guilty pleas, the final charges laid preceding the plea were counted, not just the charge pled. For details on Abdehaleem's prosecution, see Abdelhaleem Sentencing, supra note 11 at paras 83-85; PPSC ATIP Request re Terrorism Prosecutions as of 16 May 2016 [on file with authors] [PPSC ATIP Request].

28 Isabel Teotonio, "Four Have Terror Charges Stayed," The Toronto Star (15 April 2008), online: <the star.com/news/gta/2008/04/15/four_have_terror_charges_stayed.html $>$ [Teotonio, "Terror Charges Stayed"]. 


\begin{tabular}{|c|c|c|c|}
\hline Name of Accused & Style of Cause & Charges & Verdict \\
\hline Fahim Ahmad ${ }^{29}$ & R. v. Ahmad & $\begin{array}{l}83.18 \\
83.21 \\
83.2(103)\end{array}$ & $\begin{array}{l}\text { Pled guilty on all counts } \\
\text { Sentence: } 16 \text { years }\end{array}$ \\
\hline Misbahuddin Ahmed $^{30}$ & R. v. Ahmed & $\begin{array}{l}83.18 \\
83.19(465(1)(\mathrm{c})) \\
83.2(81(1)(\mathrm{d}))\end{array}$ & $\begin{array}{l}\text { Guilty at trial on } 2 \text { counts } \\
\text { Sentence: } 12 \text { years }\end{array}$ \\
\hline Ayanle Hassan $\mathrm{Ali}^{31}$ & $\begin{array}{l}\text { R. v. Ayanle Hassan } \\
\text { Ali }\end{array}$ & $\begin{array}{l}83.2 \text { (239) (3 counts) } \\
83.2 \text { (267(b)) ( } 2 \text { counts) } \\
83.2(267(\mathrm{a})) \text { ( } 3 \text { counts) } \\
83.2(88(1))\end{array}$ & Acquitted at trial \\
\hline Hiva Mohammad Alizadeh ${ }^{32}$ & R. v. Alizadeh & $\begin{array}{l}83.18 \\
83.19(465(1)(\mathrm{c})) \\
83.2(81(1)(\mathrm{a}))\end{array}$ & $\begin{array}{l}\text { Pled guilty to } 83.2 \\
\text { Sentence: } 24 \text { years }\end{array}$ \\
\hline Zakaria Amara $^{33}$ & R. v. Amara & $\begin{array}{l}83.18(465(1)(\mathrm{c})) \\
83.18 \\
83.2(81(1)(\mathrm{a})) \\
83.21\end{array}$ & $\begin{array}{l}\text { Pled guilty to } 83.18 \text { and } \\
83.2 \\
\text { Sentence: } \text { Life }+9 \text { years }\end{array}$ \\
\hline Asad Ansari ${ }^{34}$ & R. v. Ansari & 83.18 & $\begin{array}{l}\text { Guilty at trial } \\
\text { Sentence: } 6 \text { years, } 5 \\
\text { months }\end{array}$ \\
\hline Steven Vikash Chand ${ }^{35}$ & R. v. Chand & $\begin{array}{l}83.18 \\
83.2(380(1), 464(a))\end{array}$ & $\begin{array}{l}\text { Guilty at trial on all } \\
\text { counts } \\
\text { Sentence: } 10 \text { years }\end{array}$ \\
\hline Mouna Diab ${ }^{36}$ & - & 83.2 & Charges stayed \\
\hline Ali Mohammed Dirie ${ }^{37}$ & R. v. Dirie & 83.18 & $\begin{array}{l}\text { Pled guilty } \\
\text { Sentence: } 7 \text { years }\end{array}$ \\
\hline
\end{tabular}

$R v$ Ahmad, 2010 ONSC 5874 at para 72; PPSC ATIP Request, supra note 27.

Ahmed Sentencing, supra note 11 at para 110; PPSC ATIP Request, ibid.

Ali, supra note 11 .

$R v$ Alizadeh, 2014 ONSC 5421 [Alizadeh Sentencing] at para 3; PPSC ATIP Request, supra note 27. $R v$ Amara, 2010 ONSC 441 at paras 159-62 [Amara 25 February 2009 Indictment].

$R v$ Ansari, 2010 ONSC 5455 at paras 20-22.

$R v$ Chand, 2010 ONSC 6538 at paras 93-95; Amara 25 February 2009 Indictment, supra note 33.

Stewart Bell, "Quebec Muslim Activist Becomes First Woman Charged Under 9/11 Terror Laws Over Hezbollah Gun-Running Plot," National Post (13 July 2012), online: <nationalpost.com/news/ canada/quebec-woman-who-fought-against-muslim-stereotypes-charged-with-terrorism-in-allegedhezbollah-weapons-smuggling-plot>.

$37 \quad R v$ Dirie, 2009 CanLII 58598 (Ont Sup Ct J) at para 73 [Dirie]. 


\begin{tabular}{|c|c|c|c|}
\hline Name of Accused & Style of Cause & Charges & Verdict \\
\hline Sabrine Djermane ${ }^{38}$ & R. c. Jamali & $\begin{array}{l}83.181 \\
83.19 \\
83.2(81(1)(d))\end{array}$ & $\begin{array}{l}\text { Acquitted at trial on all } \\
\text { counts }\end{array}$ \\
\hline Amin Mohamed Durrani ${ }^{39}$ & R. v. Durrani & 83.18 & $\begin{array}{l}\text { Pled guilty } \\
\text { Sentence: } 7 \text { years, } 6 \\
\text { months }\end{array}$ \\
\hline Chiheb Esseghaier ${ }^{40}$ & R. v. Esseghaier & $\begin{array}{l}83.2(248,465(1)(\mathrm{c})) \\
83.2(229,465(1)(\mathrm{a})) \\
83.18(3 \text { counts })\end{array}$ & $\begin{array}{l}\text { Guilty at trial on all } \\
\text { counts } \\
\text { Sentence: Life + Life } \\
\text { concurrent + } 18 \text { years } \\
\text { concurrent }\end{array}$ \\
\hline Saad Gaya ${ }^{41}$ & R. v. Gaya & $\begin{array}{l}83.2(81(1)(a)) \\
83.18\end{array}$ & $\begin{array}{l}\text { Pled guilty on } 83.2 \\
\text { Sentence: } 18 \text { years }\end{array}$ \\
\hline Ahmad Mustafa Ghany ${ }^{42}$ & - & 83.18 ( 2 counts $)$ & Charges stayed \\
\hline Ismaël Habib ${ }^{43}$ & R. c. Habib & 83.181 & $\begin{array}{l}\text { Guilty at trial } \\
\text { Sentence: } 8 \text { years }\end{array}$ \\
\hline Othman Ayed Hamdan ${ }^{44}$ & R. v. Hamdan & $\begin{array}{l}83.2(464(a), 235) \\
83.2(464(a), 267(b)) \\
83.2(464(a), 430) \\
83.22\end{array}$ & $\begin{array}{l}\text { Acquitted at trial on all } \\
\text { counts }\end{array}$ \\
\hline Mohamed Hassan Hersi ${ }^{45}$ & R. v. Hersi & $\begin{array}{l}83.18(463(b)) \\
83.18(464(a))\end{array}$ & $\begin{array}{l}\text { Guilty at trial on all } \\
\text { counts } \\
\text { Sentence: } 10 \text { years }\end{array}$ \\
\hline Qayyum Abdul Jamal ${ }^{46}$ & - & $\begin{array}{l}83.18(2 \text { counts }) \\
83.2(81(1)(a))\end{array}$ & Charges stayed \\
\hline El Mahdi Jamali ${ }^{47}$ & R. c. Jamali & $\begin{array}{l}83.181 \\
83.19 \\
83.2(81(1)(d))\end{array}$ & $\begin{array}{l}\text { Acquitted at trial on } \\
\text { terrorism offences; guilty } \\
\text { on } 81(1)(d)\end{array}$ \\
\hline
\end{tabular}

"Montreal Couple Cleared of Terror Charges, Boyfriend Guilty of Explosives-Related Offence," CBC News (19 December 2017), online: <cbc.ca/news/canada/montreal/montreal-couple-cleared-of-terrorcharges-boyfriend-guilty-of-explosives-related-offence-1.4452720> ["Montreal Couple Cleared"]; Jamali, supra note 11.

39 Bob Mitchell \& Isabel Teotonio, “Toronto 18 Member Pleads Guilty," The Star (20 January 2010), online: <thestar.com/news/gta/2010/01/20/toronto_18_member_pleads_guilty.html>.

Esseghaier Sentencing, supra note 11 at paras $125-26$.

$R v$ Gaya, 2010 ONCA 860 at paras 18-20 [Gaya]; Amara 25 February 2009 Indictment, supra note 33. Teotonio, "Terror Charges Stayed," supra note 28.

Habib Sentencing, supra note 11 at paras 56-57.

Public Prosecution Service of Canada, News Release, "Not Guilty Verdict in Terrorism Trial" (22 September 2017), online: <ppsc-sppc.gc.ca/eng/nws-nvs/2017/22_09_17.html>; Hamdan Trial, supra note 11 at para 195 .

45 Hersi Sentencing, supra note 11 at paras 87-88.

46 Teotonio, "Terror Charges Stayed," supra note 28.

"Montreal Couple Cleared," supra note 38; Jamali, supra note 11. 


\begin{tabular}{|c|c|c|c|}
\hline Name of Accused & Style of Cause & Charges & Verdict \\
\hline Jahmaal James $^{48}$ & - & 83.18 & $\begin{array}{l}\text { Pled guilty } \\
\text { Sentence: } 7 \text { years, } 7 \\
\text { months }\end{array}$ \\
\hline Raed Jaser ${ }^{49}$ & R. v. Esseghaier & $\begin{array}{l}83.18(2 \text { counts }) \\
83.2(229,465(1)(\mathrm{a})) \\
83.2(248,465(1)(\mathrm{c}))\end{array}$ & $\begin{array}{l}\text { Guilty at trial on } 3 \text { counts } \\
\text { Sentence: Life }+13 \text { years } \\
\text { concurrent }\end{array}$ \\
\hline JR (Alberta Youth) ${ }^{50}$ & - & $\begin{array}{l}83.181 \\
83.202\end{array}$ & Charges stayed \\
\hline Saad Khalid ${ }^{51}$ & R. v. Khalid & $\begin{array}{l}83.18 \text { ( } 2 \text { counts }) \\
83.2(81(1)(a))\end{array}$ & $\begin{array}{l}\text { Pled guilty on } 83.2 \\
\text { Sentence: } 20 \text { years }\end{array}$ \\
\hline Momin Khawaja ${ }^{52}$ & R. v. Khawaja & $\begin{array}{l}83.2(81(1)(a)) \\
83.2(81(1)(d)) \\
83.18(2 \text { counts }) \\
83.19 \\
83.21,83.03(a)\end{array}$ & $\begin{array}{l}\text { Guilty at trial on } 5 \text { counts } \\
\text { Sentence: Life }+24 \text { years } \\
\text { concurrent }\end{array}$ \\
\hline Amanda Korody ${ }^{53}$ & R. v. Nuttall & $\begin{array}{l}83.2(229,465(1)(\mathrm{a})) \\
83.2(431.2(2), 465(1)(\mathrm{c})) \\
83.19 \\
83.2(81(1)(\mathrm{d}))\end{array}$ & $\begin{array}{l}\text { Guilty on } 3 \text { counts at trial; } \\
\text { charges stayed following } \\
\text { entrapment application }\end{array}$ \\
\hline Carlos Larmond ${ }^{54}$ & R. v. Larmond & $\begin{array}{l}83.18 \\
83.18(465(1)(\mathrm{c})) \\
83.181 \\
83.2(264.1) \\
83.2(464(\mathrm{a}), 235)\end{array}$ & $\begin{array}{l}\text { Pled guilty to } 83.181 \\
\text { Sentence: } 7 \text { years }\end{array}$ \\
\hline Ashton Larmond $d^{55}$ & R. v. Larmond & $\begin{array}{l}83.18 \\
83.21 \\
83.19 \\
83.18\end{array}$ & $\begin{array}{l}\text { Pled guilty to } 83.21 \\
\text { Sentence: } 17 \text { years }\end{array}$ \\
\hline LSJPA (Quebec youth) ${ }^{56}$ & R. v. LSJPA - 1557 & $\begin{array}{l}83.181 \\
83.2(344)\end{array}$ & $\begin{array}{l}\text { Guilty at trial on all } \\
\text { counts } \\
\text { Sentence: } 2 \text { years }\end{array}$ \\
\hline
\end{tabular}

$48 \quad$ Isabel Teotonio, "Toronto 18 Terrorist Freed After Guilty Plea," The Star (27 February 2010), online: $<$ thestar.com/news/gta/2010/02/27/toronto_18 terrorist_freed_after_guilty_plea.html $>$.

Esseghaier Sentencing, supra note 11 at para $\overline{126 .}$

Gareth Hampshire, “Terror Charges Stayed Against Alberta Teen," CBC News (23 September 2016), online: <cbc.ca/news/canada/edmonton/terror-charges-stayed-against-alberta-teen-1.3776673>.

$R v$ Khalid, 2010 ONCA 861 at paras 57-58 [Khalid]; Amara 25 February 2009 Indictment, supra note 33.

$R v$ Khawaja, 2010 ONCA 862 at paras 255-56 [Khawaja ONCA].

Nuttall Entrapment Application, supra note 11 at paras 836-37.

$R v$ Larmond, 2016 ONSC 5479 at para 10 [Larmond].

Ibid at para 7 .

LSJPA - 1557, supra note 11; Public Prosecution Service of Canada, News Release, "Youth Sentenced for Terrorism" (6 April 2016), online: <ppsc-sppc.gc.ca/eng/nws-nvs/2016/06_04_16.html>. 


\begin{tabular}{|c|c|c|c|}
\hline Name of Accused & Style of Cause & Charges & Verdict \\
\hline Suliman Mohamed ${ }^{57}$ & R. v. Larmond & $\begin{array}{l}83.18 \\
83.18(465(1)(\mathrm{c}))\end{array}$ & $\begin{array}{l}\text { Pled guilty to } 83.18 \\
(465(1)(c)) \\
\text { Sentence: } 7 \text { years }\end{array}$ \\
\hline Yasin Abdi Mohamed $^{58}$ & - & 83.18 ( 2 counts $)$ & Charges stayed \\
\hline Kevin Omar Mohamed ${ }^{59}$ & - & 83.18 & $\begin{array}{l}\text { Pled guilty } \\
\text { Sentence: } 4 \text { years, } 6 \\
\text { months }\end{array}$ \\
\hline Saïd Namouh ${ }^{60}$ & R. v. Namouh & $\begin{array}{l}83.18 \\
83.19 \\
83.2(346)\end{array}$ & $\begin{array}{l}\text { Guilty at trial on all } \\
\text { counts } \\
\text { Sentence: Life }+20 \text { years } \\
\text { concurrent }\end{array}$ \\
\hline John Stuart Nuttall ${ }^{61}$ & R. v. Nuttall & $\begin{array}{l}83.2(229,465(1)(\mathrm{a})) \\
83.2(431.2(2), 465(1)(\mathrm{c})) \\
83.19 \\
83.2(81(1)(\mathrm{d}))\end{array}$ & $\begin{array}{l}\text { Guilty on } 3 \text { counts at trial; } \\
\text { charges stayed following } \\
\text { entrapment application }\end{array}$ \\
\hline Khurram Syed Sher ${ }^{62}$ & R. v. Sher & 83.19 & Acquitted at trial \\
\hline Prapaharan Thambaithurai ${ }^{63}$ & R. v. Thambaithurai & 83.03(b) & $\begin{array}{l}\text { Pled guilty } \\
\text { Sentence: } 6 \text { months }\end{array}$ \\
\hline Toronto Youth 18 Youth $1^{64}$ & - & 83.18 & Charges stayed \\
\hline Toronto Youth 18 Youth $2^{65}$ & - & 83.18 & Charges stayed \\
\hline Toronto Youth 18 Youth $3^{66}$ & - & 83.18 & Charges withdrawn \\
\hline Nishanthan Yogakrishnan $^{67}$ & R. v. N.Y. & 83.18 & $\begin{array}{l}\text { Guilty at trial } \\
\text { Sentence: } 2 \text { years, } 6 \\
\text { months }\end{array}$ \\
\hline
\end{tabular}

Larmond, supra note 54 at para 13.

Teotonio, "Terror Charges Stayed," supra note 28.

Public Prosecution Service of Canada, News Release, "Sentence in Terrorism Case" (31 October 2017), online: <ppsc-sppc.gc.ca/eng/nws-nvs/2017/31 10 17.html>.

$R$ c Namouh, 2010 QCCQ 943 at paras 103-105 [Namouh Sentencing].

Nuttall Entrapment Application, supra note 11 at paras 836-37.

Sher, supra note 11 at para 79.

$R v$ Thambaithurai, 2010 BCSC 1949 at para 21 [Thambaithurai Trial].

See Nesbitt, supra note 11 at 108.

Ibid.

Ibid.

Yogakrishnan was convicted as a youth, but was sentenced as an adult. See NY Trial, supra note 12 at paras 282-83; RvNY, [2009] OJ No 6495 (QL) at para 25 (Sup Ct J) [NY Sentencing]; "Ban Lifted on Convicted Terrorist's Identity," CBC News (9 September 2009), online: <cbc.ca/news/canada/toronto/ ban-lifted-on-convicted-terrorist-s-identity-1.778966>. 


\begin{tabular}{|c|c|c|l|}
\hline Name of Accused & \multicolumn{1}{|c|}{ Style of Cause } & \multicolumn{1}{c|}{ Charges } & \multicolumn{1}{c|}{ Verdict } \\
\hline CC (Manitoba Youth ${ }^{68}$ & - & $83.2(464(\mathrm{a}), 267)$ & $\begin{array}{l}\text { Pled guilty } \\
\text { Sentence: } 20 \text { months } \\
\text { (including 6 months } \\
\text { deferred) }\end{array}$ \\
\hline
\end{tabular}

Nineteen of the 42 individuals prosecuted were tried in one of the 15 terrorism trials that have been held since 2001. These 15 trials have resulted in five acquittals and 12 convictions (although two more convictions were converted to stays after an entrapment application). As well, 14 people have pled guilty to terrorism offences (13 before trial, one mid-trial). In total, 26 people have been convicted or have pled guilty to terrorism charges since the introduction of the Part II.1 terrorism offences in 2001. ${ }^{69}$

Of these prosecutions, the participation offence (section 83.18) and the commission of an offence for a terrorist group (section 83.2) are the most favoured provisions. The table below reproduces the five most commonly charged provisions to date, including the number of times each offence was charged and the number of convictions on each offence. ${ }^{70}$

\begin{tabular}{|l|l|l|l|}
\hline Criminal Code Section & $\begin{array}{l}\text { Numbers of } \\
\text { Counts Charged }\end{array}$ & $\begin{array}{l}\text { Number of } \\
\text { Counts Convicted }^{72}\end{array}$ & Average Sentence $^{73}$ \\
\hline Participation (s. 83.18) & 43 & 22 & 6.09 years \\
\hline $\begin{array}{l}\text { Leaving Canada to participate } \\
\text { (s. 83.181) }\end{array}$ & 6 & 3 & 7.5 years \\
\hline Facilitation (s. 83.19) & 10 & 3 & 6 years \\
\hline $\begin{array}{l}\text { Commission of an indictable } \\
\text { offence for the benefit of a terrorist } \\
\text { group (s. 83.2) }\end{array}$ & 41 & 13 & 18.18 years \\
\hline Instructing (s. 83.21) & 4 & 3 & 11 years \\
\hline
\end{tabular}

The table below breaks down numerically the number of trials, including the individuals tried and, significantly, the number of judgments and constitutional challenges to the

68 Public Prosecution Service of Canada, News Release, "Youth Sentenced for Terrorism Offence" (9 January 2017), online: <ppsc-sppc.gc.ca/eng/nws-nvs/2017/09_01_17.html>.

For a further discussion of those convicted of terrorism offences in Canada, see Nesbitt, supra note 11. For more on the charging patterns in terrorism prosecutions to date, see Nesbitt, ibid.

This column excludes those charges laid in absentia or in ongoing prosecutions. As well, where an accused's prosecution proceeded to trial, only those charges that were tried are counted. Where an accused pled guilty, the total counts the final charges that were laid, as reported in decisions or news releases. Thus, the total counts not just those charges that the accused pled guilty to.

72 Excludes youth convictions where no information is publicly available.

Excludes youth sentences and probation orders. 
terrorism offences upon which we can draw to analyze judicial reasoning related to the elements of the terrorism crimes.

\begin{tabular}{|ll|}
\hline Total resolved prosecutions $^{74}$ & 42 \\
\hline Trials to date $^{7}$ & 15 \\
\hline Trials by jury & 6 \\
\hline Trials by judge alone & 9 \\
\hline Constitutional challenges, trial judgments, and appeals & \\
\hline Trial judgments & 9 \\
\hline Decisions involving constitutional challenges & 9 \\
\hline Trial court decisions & 5 \\
\hline Provincial appellate court decisions & 2 \\
\hline Supreme Court of Canada decisions & 2 \\
\hline
\end{tabular}

There have only been nine judge-alone trials, which means that there are only nine trial judgments that engage with the elements of the offences charged. ${ }^{75}$ The first of these - and by far the most important - is the prosecution of Momin Khawaja, a young man who became involved in a UK terrorist cell and a fertilizer bomb plot, which is the only case in which the Supreme Court of Canada has opined on the Part II.1 terrorism offences. ${ }^{76}$ There have also been 15 appellate court decisions, including ten that have been rendered by the Ontario Court of Appeal and two by the Supreme Court of Canada. ${ }^{77}$ There have also been six constitutional challenges to the Part II.1 provisions, including to the definition of "terrorist activity" in section 83.01(1) and to the participation in the activity of a terrorist group offence under section 83.18. These challenges have resulted in eight decisions, the most important of which was again the Supreme Court's decision in the Khawaja case, and was a companion case to the Nadarajah and Sriskandarajah extradition cases. ${ }^{78}$ R. v. Hersi

74 For a list of all terrorism prosecutions, see Nesbitt, supra note 11. For the list of resolved terrorism prosecutions only, see pages 600-605 above.

$75 \quad$ Khawaja ONSC, supra note 12; NY Trial, supra note 12; R c Namouh, 2009 QCCQ 9324 [Namouh Trial]; Sher, supra note 11; LSJPA - 1557, supra note 11; R c Habib, 2017 QCCQ 6948 [Habib Trial]; Hamdan Trial, supra note 11; Ali, supra note 11. Shareef Abdelhaleem was also tried by judge alone, but at the conclusion of the Crown's case, the accused conceded that the Crown had proved the essential elements of the offence and applied to stay the proceedings on the basis of entrapment: $R v$ Abdelhaleem, [2010] OJ No 5693 (QL) (Sup Ct J) at para 4.

76 Khawaja ONSC, supra note 12; Khawaja ONCA, supra note 52; $R$ v Khawaja, 2012 SCC 69 [Khawaja SCC].

77 The full list of appellate decisions is as follows: Toronto Star Newspapers Ltd $v$ Canada, 2009 ONCA $59 ; R \vee$ Ahmed, 2017 ONCA 76 [Ahmed ONCA]; $R$ v Esseghaier, 2017 ONCA 970; $R$ v Ansari, 2015 ONCA 575; $R$ v Ansari, 2015 ONCA 891; Khawaja SCC, ibid; $R v$ Ahmad, 2011 SCC 6; $R v N Y, 2012$ ONCA 745; $R$ v Thambaithurai, 2011 BCCA 137; $R$ v Amara, 2010 ONCA 858; Gaya, supra note 41; Khalid, supra note 51; Khawaja ONCA, supra note 52; Canada (AG) v Khawaja, 2007 FCA 342; Khawaja v Canada (AG), 2007 FCA 388.

${ }_{78} \quad R v$ Khawaja, 2006 CanLII 63685 (Ont Sup Ct J) [Khawaja Constitutional Challenge], rev'd 2010 ONCA 862, 2012 SCC 69; United States of America v Sriskandarajah, 2012 SCC 70; R v NY, 2008 CanLII 24543 (Ont Sup Ct J) [NY Constitutional Challenge]; $R v$ Ahmad, 2009 CanLII 84774 (Ont Sup Ct J) [Ahmad Constitutional Challenge]; United States of America v Nadarajah (2009), 95 OR (3d) 514 (Sup Ct J) [Nadarajah ONSC], aff'd 2010 ONCA 859; R c Namouh, 2009 QCCQ 5833 [Namouh Constitutional Challenge]; $R v$ Hersi, 2014 ONSC 1217 [Hersi Constitutional Challenge]. There was also a challenge to the investigative hearings regime under section 83.28 of the Criminal Code, which 
is the only constitutional challenge post-dating the Supreme Court's sweeping constitutionality finding in Khawaja, and Mohamed Hersi's defence counsel drew a sharp rebuke for his "poorly disguised efforts to rehash issues already decided by the Supreme Court of Canada." 79

These trial judgments and constitutional challenges represent a fraction of the total number of reported decisions. In total, there are at least 157 reported decisions to date: 133 from a provincial superior court, nine from the Federal Court, and 15 from a court at the appellate level (as already noted). ${ }^{80}$ An Ontario court authored the vast majority of these decisions: 89 are from the Ontario Superior Court, 34 are from the British Columbia Supreme Court, nine are from the Quebec Superior Court, and one is from the Alberta Court of Queen's Bench. As well, a small handful of Ontario judges authored a large proportion of these judgments. Justices Fletcher Dawson and Bruce Durno wrote 45 decisions during the Toronto 18 trials, while Justices Colin McKinnon and Michael Code alone authored 17 decisions. ${ }^{81}$

Finally, to date there have been no charges laid for a number of terrorism offences, including: ${ }^{82}$ providing or collecting property for certain activities (section 83.02 ); using or possessing property for terrorist purposes (section 83.04); leaving Canada to facilitate terrorist activity (section 83.191); advocating or promoting commission of terrorism offences (section 83.221) ${ }^{83}$ and concealing a person who carried out terrorist activity (section 83.23). Two other provisions have been charged but have yet to receive judicial consideration: leaving Canada to commit offence for terrorist group (section 83.201) and leaving Canada to commit offence that is terrorist activity (section 83.202). ${ }^{84}$

With this data on terrorism prosecutions in mind, let us now turn to the judgments themselves to see what they have said about the offences charged to date. In particular, we will focus on the elements of the offences and how the courts have interpreted the mens rea and actus reus of the offences as well as the predicates thereto.

marked the first occasion where the Supreme Court of Canada opined on the purpose of the Part II.1 Criminal Code provisions: Application under s 83.28 of the Criminal Code (Re), 2004 SCC 42.

79 Hersi Constitutional Challenge, ibid at para 44.

80 This total is arrived at through searching for reported decisions on QuickLaw, WestLaw Next, and CanLII. The full list of reported decisions related to terrorism prosecutions is on file with the authors. 81 Colin McKinnon handled the related prosecutions of Misbahuddin Ahmed, Khurram Syed Sher, and Hiva Alizadeh: see Ahmed Sentencing, supra note 11; Sher, supra note 11; Alizadeh Sentencing, supra note 32. Michael Code presided over the prosecutions of Chiheb Esseghaier and Raed Jaser: Esseghaier Sentencing, supra note 11 .

82 See Nesbitt, supra note 11 at 22, n 118 , for a brief discussion of the provisions not yet charged and the implications arising from the lack of charges under certain provisions.

83 See Nesbitt, ibid, for a brief discussion of the advocating provision and why it may not yet have been charged.

84 An Alberta youth was charged under section 83.201, but his charges were stayed: Hampshire, supra note $50 ; R v J R, 2015$ ABQB 712 at para 1. Hasibullah Yusufzai was charged in absentia under section 83.202: Colin Freeze \& Sunny Dhilon, "B.C. Man First to Be Charged under New Terrorism Law," The Globe and Mail (24 July 2014) A1. 


\section{JUDICIAL INTERPRETATIONS OF THE ELEMENTS OF TERRORISM OFFENCES}

Both the Supreme Court and Parliament asserted early on that the Criminal Code's Part II.1 terrorism offences were created to respond, in the first place, to the need to investigate and charge for terrorism before the violent acts came to fruition. ${ }^{85}$ Consequently, the actus reus of each offence generally plays a (relatively) limited role because it attaches to acts that are merely preparatory in nature ${ }^{86}$ In turn, the mens rea of each offence acts as a critical control mechanism limiting the scope of the offences in order to prevent the offences from being unconstitutionally overbroad. There have been numerous constitutional challenges to the terrorism provisions. As will be discussed below, the resulting jurisprudence reads in a number of substantive mental elements that are not readily discernible from the text of the provisions. ${ }^{87}$

In this section of the article, we summarize the jurisprudence on the Part II.1 Criminal Code terrorism provisions with a view to providing a comprehensive, stand-alone guide on each provision. As background, we begin with the controversial definitions of "terrorist activity" and "terrorist group," which are predicates to all but one of the offence-creating provisions. ${ }^{88}$ Then, we proceed with an overview of each terrorism offence, providing prosecutorial context where appropriate, and noting outstanding interpretive controversies as they arise. ${ }^{89}$

\section{A. Definitions (SECTION 83.01)}

\section{DEFINITION OF "TERRORIST ACTIVITY”}

The definition of "terrorist activity" found in section 83.01 of the Criminal Code does not itself create an offence, but it is of primary importance to the Criminal Code terrorism offences. ${ }^{90}$ It acts as a predicate, directly or indirectly, to virtually every offence in Part II.1 of the Criminal Code: every terrorism offence under Part II.1 refers to the definition of

For a discussion, see Khawaja SCC, supra note 76 at para 63; Nadarajah ONCA, supra note 6 at paras 32-35; Ahmad Constitutional Challenge, supra note 78 at paras 67-71. See also Kent Roach, September 11: Consequences for Canada (Montreal: McGill-Queen's University Press, 2003) at 38. With the exception of section 83.2, which requires as a predicate the commission of an indictable offence (for the benefit of a terrorist group). However, as noted in the section on that provision below, the heightened actus reus element is offset by a lower mens rea than the other terrorism offences. Khawaja Constitutional Challenge, supra note 78, rev'd Khawaja ONCA, supra note 52; Khawaja SCC, supra note 76; Nadarajah ONCA, supra note 6; Ahmad Constitutional Challenge, supra note 78; $N Y$ Constitutional Challenge, supra note 78; Hersi Constitutional Challenge, supra note 78; Namouh Constitutional Challenge, supra note 78.

$$
\text { Except section } 83.221 \text { (advocating or promoting commission of terrorism offences). }
$$

We do not discuss those sections that were not discussed substantively within the jurisprudence, such as section 83.21 (instructing to carry out activity for terrorist group), or those offences that have not yet been charged or adjudicated at all, such as sections 83.02 (providing or collecting property for certain activities), 83.04 (using or possessing property for terrorist purposes), 83.191 (leaving Canada to facilitate terrorist activity), 83.201 (leaving Canada to commit offence for terrorist group), 83.202 (leaving Canada to commit offence that is terrorist activity), and 83.221 (advocating or promoting commission of terrorism offences). 
"terrorist activity" either directly or indirectly through the definition of "terrorist group," which in turn incorporates the definition of "terrorist activity." 91

\section{a. Structure of the Definition}

Section 83.01(1) of the Criminal Code creates two broad categories of terrorist activity. The first captures acts that would constitute offences under section 7 of the Criminal Code, which incorporates into Canadian criminal law a number of international treaties concerning aviation, hostage-taking, nuclear weapons, terrorism bombings and financing, and so forth. ${ }^{92}$ This category of terrorist activity has not yet been expressly relied upon in any reported decisions.

The second category of terrorist activity set out in the Criminal Code is a newly defined category of conduct, which underpins all judicial decisions to date. The Supreme Court in Khawaja summarized this definition of "terrorist activity" as neatly as possible given the definition's length and complexity. ${ }^{93}$ In brief, "terrorist activity" involves an act, omission, conspiracy, attempt, threat, counselling, or being an accessory after the fact to an act or omission, committed in or outside Canada. ${ }^{94}$ The conduct must intentionally cause one of the five following consequences (the "consequence clause"):

(A) causes death or serious bodily harm to a person by the use of violence,

(B) endangers a person's life,

(C) causes a serious risk to the health or safety of the public or any segment of the public,

(D) causes substantial property damage, whether to public or private property, if causing such damage is likely to result in the conduct or harm referred to in clauses (A) to (C), or

(E) causes serious interference with or serious disruption of an essential service, facility or system, whether public or private, other than as a result of advocacy, protest, dissent or stoppage of work ${ }^{95}$ that is not intended to result in the conduct or harm referred to in any of clauses (A) to (C). ${ }^{96}$ Cf sections 83.02-83.04, 83.18-83.22. The only offence under Part II.1 that does not expressly incorporate the definition of either "terrorist activity" or "terrorist group" is the advocating or promoting of "terrorism offences in general" (section 83.221).

Hersi Constitutional Challenge, supra note 78 at para 7; Ahmad Constitutional Challenge, supra note 78 at para 18; Robert Diab, "Canada" in Kent Roach, ed, Comparative Counter-Terrorism Law (New York: Cambridge University Press, 2015) 78 at 80; Forcese, National Security Law, supra note 2 at 263-64.

Subject to the "armed conflict exception," discussed below.

The first draft of this provision only excluded "lawful advocacy, protest, dissent or stoppage of work," but the word "lawful" was removed after the Bill's second reading: Kent Roach, "Canada's New AntiTerrorism Law" (2002) 44:1 Sing JLS 122 at 131; Bill C-36, An Act to amend the Criminal Code, the Official Secrets Act, the Canada Evidence Act, the Proceeds of Crime (Money Laundering) Act and other Acts, and to enact measures respecting the registration of charities in order to combat terrorism, 1st Sess, 37th Parl, 2001, cl 4, sub verbo "terrorist activity” (assented to 18 December 2001). 
The definition of terrorist activity also requires that the impugned conduct must be committed:

(A) in whole or in part for a political, religious or ideological purpose, objective or cause (the motive clause); and

(B) with the intention of intimidating the public or a segment of the public as regards its security, or to compel a person, government, or organization — whether inside or outside Canada — to do or refrain from doing any act (the purpose clause). ${ }^{97}$

Justice Dawson in his decision on the constitutional challenge by the Toronto 18 accused, noted that the consequence clause $(\mathrm{E})$ is particularly "awkwardly drafted":

(E) causes serious interference with or serious disruption of an essential service, facility, or system, whether public or private, other than as a result of advocacy, protest, dissent or stoppage of work that is not intended to result in the conduct or harm referred to in any of clauses $(A)$ to $(C) .^{98}$

He notes that on a "proper grammatical construction," the two halves of the bracketed portion are coupled, so clause (E) potentially captures non-violent conduct. ${ }^{99}$ On this construction, the only non-violent activity excluded under the clause is advocacy, protest, or dissent that is not intended to result in the consequences enumerated in clauses $\mathrm{A}-\mathrm{C}$. Other forms of non-violent activity are captured, like dissent intended to result in the consequences enumerated in clauses A-C or (more broadly) any non-violent activity other than advocacy, dissent, and protest. But the Supreme Court in Khawaja disagreed, holding that clause E is wholly "confined to the realm of acts of violence and threats of violence." 100 The Supreme Court found that clause E actually emphasizes an activity having a "serious interference" or "serious disruption" and a harm listed in clauses A-C as an intended result. The Supreme Court's interpretation thus removes a "large slice" of non-violent expressive activity from the scope of clause E, even though a more natural reading of the clause might suggest otherwise.

\section{b. Constitutionality of the Definition of "Terrorist Activity"}

Neither the definition of "terrorist activity" nor the motive clause constitute a criminal offence in and of themselves; again, they serve as elements of the predicates for those offences. ${ }^{101}$ Nevertheless, there has been significant controversy regarding the constitutionality of the definition of terrorist activity that is worth canvassing briefly precisely because terrorist activity forms the backbone to the terrorist offences regime. ${ }^{102}$

$97 \quad$ Criminal Code, ibid, s 83.01(1)(b)(i)(A)-(B).

98 Ahmad Constitutional Challenge, supra note 78 at para 105; cf Criminal Code, supra note 2, s 83.01(1)(b)(ii)(E) [emphasis added]. The lower Court in Nadarajah also noted that this language was "less than clear," but held that read in its context, it did not violate sections 2(b) or (d) of the Charter: Nadarajah ONSC, supra note 78 at paras 34-35, aff'd Nadarajah ONCA, supra note 6.

99 Ahmad Constitutional Challenge, ibid at para 106.

$100 \quad$ Khawaja SCC, supra note 76 at para 73.

$101 \quad$ Khawaja ONCA, supra note 52 at para 76; Hamdan Trial, supra note 11 at paras 43-44.

102 Professor Kent Roach has provided many of the most erudite, compelling critiques of the Criminal Code's definition of terrorist activity - and he in fact worked on the legal challenge to the definition in Khawaja. See e.g. Kent Roach, "Terrorism Offences and the Charter: A Comment on R v. Khawaja" (2007) 11:3 Can Crim L Rev 271 [Roach, “Terrorism Offences and the Charter"]. 
The definition of "terrorist activity" requires the Crown to prove the existence of a "political, religious or ideological" motive, as noted above. ${ }^{103}$ Roach has argued that the inclusion of a motive requirement marked a "disconcerting departure" from the traditional principle that "no motive excuses the commission of a crime"; ${ }^{104}$ and, in doing so, the motive requirement would make "the politics and religion of accused terrorists a central feature of their criminal trials." 105 In the purported result, the definition of terrorism risks contributing to an environment where certain ideologies and religions are stigmatized by virtue of their association with religion. However, courts have not been so persuaded, at least as concerns the unconstitutionality of the definition, and the issue seems to have been put to rest.

According to the British Columbia Supreme Court in the Hamdan decision, the definition of terrorist activity "dovetail[s]" with the Charter protections of freedom of thought, belief, opinion, and expression. ${ }^{106}$ Section 83.01(1.1) — the motive clause - was added for greater certainty to Charter-proof the provision. ${ }^{107}$ That is, not any act committed "in whole or in part with the intention of intimidating the public ... with regard to its security ... or compelling a person, a government or a domestic or an international organization to do or to refrain from doing any act" would do (section 83.01(b)(i)(B)). Instead, that act had also to be committed "in whole or in part for a political, religious or ideological purpose" (the motive clause, section 83.01(b)(i)(A)) and had to endanger a person's life or cause "a serious risk to the health or safety of the public" and so on (sections 83.01(b)(ii)(B)-(C)). The motive clause was thus seen as a limiting factor on the types of activities that would be captured by the Criminal Code's definition of terrorist activity. Put another way, without the motive clause, the state could arguably define a greater number of activities as "terrorist" in nature.

However, this limiting intention did not prevent the trial judge in Khawaja - the very first terrorism trial in Canada - from severing the motive clause because it was an unjustifiable infringement of sections 2(a), (b), and (d) of the Charter because it would focus undue attention on the political or ideological beliefs of the accused, rather than their wrongful actions. ${ }^{108}$ This finding of unconstitutionality was reversed on appeal, and the Supreme Court upheld the constitutionality of the clause. ${ }^{109}$ The Supreme Court found that merely by focusing attention on the religious or ideological beliefs of the accused, it did not follow - there was no evidence presented at trial — that this would have a "chilling effect on the exercise of [section] 2 [Charter] freedoms." 110 Prior to that Supreme Court holding

103 Criminal Code, supra note 2, s 83.01(1)(b)(i)(A).

104 Roach, "Canada's New Anti-Terrorism Law," supra note 95 at 128-29.

105 Ibid at 128

106 Hamdan Trial, supra note 11 at para 42.

107 Roach, “Canada's New Anti-Terrorism Law," supra note 95 at 128.

108 Khawaja Constitutional Challenge, supra note 78 at paras 74-78. As stated by the Supreme Court, supra note 76 at para 10, in overturning the constitutional finding, the Superior Court "found that the effect of this 'motive clause' would be 'to focus investigative and prosecutorial scrutiny on the political, religious and ideological beliefs, opinions and expressions of persons and groups,' which in turn would produce a chilling effect on the expression of beliefs and opinions (para. 58). He found that the infringement could not be justified under [section] 1" of the Charter. 
in Khawaja, other courts also upheld the constitutionality of the definition of "terrorist activity" under both sections 2 and 7 of the Charter. ${ }^{11}$

Today, of the 12 prosecutions that have concluded since the 2012 Supreme Court decision in Khawaja, there has been only one subsequent constitutional challenge to the definition of "terrorist activity." Defence counsel for Mohamed Hersi challenged the constitutionality of the definition of "terrorist activity" on three grounds: (1) the definition is overbroad; (2) the definition violates religious and expressive freedoms under sections 2(a) and 2(b) of the Charter; and (3) the definition creates an "inchoate upon inchoate" offence when applied in the context of the participation offence under section 83.18. ${ }^{12}$ The Court did not even address the first two grounds, and forcefully reiterated both the Supreme Court's reasoning in Khawaja and the Ontario Court of Appeal's reasoning in Nadarajah in holding that there is no "inchoate upon inchoate" offence because the definition of "terrorist activity" does not itself create an offence. ${ }^{113}$ The Court concluded its reasons with a sharp rebuke of defence counsel for bringing constitutional challenges and asserted that the arguments raised "nothing new under the sun"; the Court thus found that, "[t]hese motions [were thus] a significant waste of the court's time." "114 Therefore, in light of the Supreme Court's decision in Khawaja, a challenge to the constitutionality of the definition of "terrorist activity" is unlikely to succeed.

The Supreme Court did leave a constitutional chink in the armor in the Khawaja case: the court "would not rule out the possibility" that activity protected under section 2(b) of the Charter may be captured by section 83.01(1)(b)(ii)(E) (causing serious interference with or serious disruption of an essential service). ${ }^{115}$ The scope of activity protected under section 2(b) of the Charter is wide, since it protects the form and content of any activity that conveys or attempts to convey meaning subject to few limits. ${ }^{116}$ One limit is expression that takes the form of violence or amounts to a threat of violence. ${ }^{117}$ Another limit is expression that occurs in certain public spaces. ${ }^{118}$ Thus, the Supreme Court seemingly left open the possibility that clause E tramples on non-violent expression and, perhaps less obviously, expression that would ordinarily be protected in a public space.

In practice, however, the scope of protected expression that might be trampled on by clause $\mathrm{E}$ is probably narrow. The Supreme Court found that the section is directed at serious disruptions to essential services that pose a threat to public health. This draws a parallel between clause $\mathrm{E}$ and the conduct captured in clause $\mathrm{C}$, which was found to constitute "violence," and therefore fell outside the scope of section 2(b). As a result, in most cases, only violence will amount to the type of conduct equalling a serious disruption to or interference with an essential service as captured under clause E. In turn, it will not be

\footnotetext{
111 See Ahmad Constitutional Challenge, supra note 78 at para 142; NY Constitutional Challenge, supra note 78 at para 84 .

Hersi Constitutional Challenge, supra note 78 at para 25. The "inchoate upon inchoate" argument is discussed in detail below at 626 .

Hersi Constitutional Challenge, ibid at paras 25-31.

Ibid at para 44 .

Khawaja SCC, supra note 76 at para 74.

Hon Robert J Sharpe \& Kent Roach, The Charter of Rights and Freedoms, 6th ed (Toronto: Irwin Law, 2017) at 169.

Ibid at 170 .

Ibid.
} 
protected expression precisely because only violent activity will be captured by the term "serious disruption."

Moreover, clause E explicitly excludes from its ambit advocacy, dissent, or protest that is done without an intent to result in the consequences listed in clauses $\mathrm{A}-\mathrm{C}$. This means advocacy, dissent, or protest in more conventional forms will not be captured by clause E's reach - and will instead be permitted. So, an example of activities captured by clause E would be a far-right group that set-up a non-violent blockade on a major highway. In that case, it might amount to protected expression falling under clause $\mathrm{E}$. The blockade is a nonviolent expressive activity because it does not create a health risk or involve more conventional acts of violence. And, since it might not be a form of advocacy, dissent, or protest, it cannot benefit from the carve-out for those activities. Thus, unless the Supreme Court is persuaded to wholly revisit its earlier comments, its reasoning leaves little space for clause $\mathrm{E}$ to trample on protected expression.

If such a case came to pass in the future - where an individual was charged with terrorism for a non-violent act causing serious interference with or disruption to an essential service - the issue would then become whether the infringement is justified under section 1 of the Charter. ${ }^{119}$ Clause E has at least one aspect that might help justify its trampling on protected expression in such a case. Roach noted that clause E's intent requirement ${ }^{120}$ could bolster the constitutionality of the offence under section 1 of the Charter in a similar manner to the Criminal Code's hate speech provisions by including such an intent requirement. ${ }^{121}$ In R. $v$. Keegstra, the intent requirement in the hate speech provisions helped bolster constitutionality under the section 1 analysis because the requirement ensured that the provisions were minimally impairing and focused on expression with a low value. ${ }^{122} \mathrm{~A}$ similar approach might aid clause E under a section 1 Charter analysis.

The end result is that the definition of terrorism looks relatively stable and settled in Canada. Defence lawyers are more likely to receive a rebuke for making an issue of the definition than they are to succeed. Nevertheless, clause $\mathrm{E}$ is one small exception where defence lawyers may, in the right case involving the non-violent disruption of an essential service, look to pursue a constitutional challenge down the road.

\section{DEFINITION OF "TERRORIST GROUP”}

The definition of "terrorist group," like the definition of "terrorist activity," is a predicate for approximately half of the terrorism offences under Part II. 1 of the Criminal Code. ${ }^{123}$ The definition is two-pronged: an entity is a terrorist group if either (1) it has as one of its

Khawaja SCC, supra note 76 at para 74.

That the interference or disruption must be intended to result in: (A) death or serious bodily harm to a person by the use of violence; (B) endangerment of a person's life; or (C) serious risk to the health or safety of the public or any segment thereof: ss 83.01(1)(b)(ii)(A)-(C), (E).

Roach, "Canada's New Anti-Terrorism Law," supra note 95 at 131.

$R v$ Keegstra, [1990] 3 SCR 697.

Supra note 2, ss 83.03(b) (providing or making available property or services knowing that they will be used by or will benefit a terrorist group), 83.18 (participation in activity of terrorist group), 83.181 (leaving Canada to participate in activity of terrorist group), 83.2 (commission of offence for terrorist group), 83.201 (leaving Canada to commit offence for terrorist group), and 83.21 (instructing to carry out activity for terrorist group). 
purposes or activities the facilitation or carrying out of any terrorist activity, or (2) if it is a listed entity.

"Entity" is defined in Part II.1 of the Criminal Code as a person, group, trust, partnership, fund, or an unincorporated association or organization. ${ }^{124}$ Hence, because the phrase "a person" is singular, it has traditionally been understood that a single person may constitute a "terrorist group." 125 However, Justice MacDonnell of the Ontario Superior Court inserted some uncertainty here in the case of Ali by finding, inter alia, that a proper understanding of terrorist entity as it applies to section 83.2 of the Criminal Code - committing an offence for a terrorist group - must not include "lone wolves" who are completely unassociated with any terrorist group beyond themselves. Rather, according to the Court, there must be some connection to other people (to form an independent terrorist group) or to an existing terrorist group that the accused wishes to support. Put another way, at least for the purposes of section 83.2, the accused cannot be both the actor and the group all rolled up in one. ${ }^{126}$ As the defence argued at trial and the Court adopted, "s[ection] 83.2 requires a separate identity between the defendant who commits the predicate offence and the terrorist group for whom the predicate offence was committed."

The Court's reasoning creates an interesting dilemma. On one hand, the Crown was correct in that an entity can clearly include "a person," just by virtue of its definition in the Criminal Code - recall that the Criminal Code defines an entity as, inter alia, "a person." As such, it should follow that a terrorist group should always be defined as including one or more persons. On the other hand, the Ontario Superior Court of Justice's reasoning is compelling in that there is a clearly a conceptual distinction between a person acting alone but intending to act on behalf of or at least in advancement of a group like ISIS or al-Qaida, or even a single other party, and a situation like in Ali where there was no mention of any other group or person at all, only "that killing Canadian military personnel was justified because the military was fighting in Muslim lands." 128

What we are left with, for now, is that an accused can commit a criminal act on behalf of one other person who can themselves constitute a "terrorist entity," thereby rendering the accused guilty of a section 83.2 criminal offence. Again, the Ali judgment does not disrupt this interpretation. So long as there exists at least one other individual to whom the Crown can point as the terrorist entity, then the accused can act on that person's behalf. But, according to the Ontario Superior Court of Justice in Ali, if there is no (terrorist) source of inspiration - no group other than an assertion that an individual accused of the offences is also a terrorist — then that does not meet the definition of a "terrorist entity."

Herein lies the dilemma: many terrorists are labelled "lone wolves." According to the Ali judgment, the Crown admitted as much in this case when it argued that, "a self-radicalized lone-wolf who chooses to act on his own initiative can be captured by [section] 83.2." ${ }^{29}$ Yet,

\footnotetext{
$124 \quad$ Ibid, s 83.01(1), sub verbo "entity."

125 Nadarajah ONCA, supra note 6 at para 20. See also Forcese, National Security Law, supra note 2 at 274.

See Ali, supra note 11 at paras $1-5$.

Ibid at para 5, citing ibid (Factum of the Defendant at para 25). See also Ali, ibid at para 50.

Ali, ibid at para 2 .

Ibid at para 51 .
} 
social science research makes clear that so-called "lone-wolves" almost always have a network and source of inspiration, including, for example, an online community. ${ }^{130}$ Though it may have been overlooked by Crown counsel in this case, going forward what the Crown wishes to avoid is getting into a debate about the conceptual notion of a lone wolf, whether such a thing exists, and whether an individual might fit that category in a particular case. These "lone wolf" debates represent a thorny dilemma and have proved particularly intractable in the social sciences despite plenty of evidence to suggest that we should dispense with the notion all together. ${ }^{131}$ Put another way, the distinction between "selfradicalized" and otherwise inspired, between "act[ing] on his own initiative" in the words of the Court and being subtly pushed by an online community, is a slippery one. ${ }^{132}$ Indeed, it is a distinction that has proved near impossible to maintain in theory (in the academic literature) or in practice (many terrorists are both "loners" and nudged, at least online). The Crown does not wish to enter into this intractable debate where evidence will invariably be circumstantial at best and proof of inspiration hard to pin down. Even ISIS, a clear example of a (listed) terrorist entity, tends to "inspire" more so than they directly recruit. Kinetic actors (would-be perpetrators) in the West then choose - of their own volition - to follow its lead; ISIS has not traditionally directly recruited in a way that would show definitive links between centralized planning of an attack and the eventual outcome by an individual in the West. ${ }^{133}$ It is thus doubtful that the Crown, and likely the courts, wish to spend their time parsing lone wolves from inspired converts rather than engaging with the actual activities and beliefs (and motives) of the individuals. One could foresee the situation where the notion of being a "lone wolf" (someone without co-conspirators) could rear its head every time an individual is accused with the commission of an offence on behalf of a terrorist group (section 83.2) - and, again, each time it will be difficult to prove whether an individual was inspired by, say, ISIS or whether he was simply watching YouTube videos in the basement and acting of his own volition.

The Crown knows this to be true and for this reason it has been adamant about the definition of terrorist entity including one or more persons. Likewise, even if we accept that Canadian courts are willing to engage in debates about inspired lone wolves versus inspired recruits, the Ontario Superior Court of Justice's decision in the Ali case would effectively eliminate the possibility of charging true lone wolves with the section 83.2 terrorism offence. By this definition, in Canada, Timothy McVeigh, the Oklahoma City bomber, might not be a terrorist (at least based on the evidence available at the time of trial). This is because the Criminal Code does not contain a stand-alone offence for "terrorist activity"; rather, as discussed above, terrorist activity is a predicate for other terrorism offences (as is terrorist group). Section 83.2 has always been thought to cover this ground - so long as terrorist

130 See David C Hofmann, “How 'Alone' are Lone-Actors? Exploring the Ideological, Signaling, and Support Networks of Lone-Actor Terrorists" (2018) Canadian Network for Research on Terrorism, Security and Society Working Paper No 18-02, online: <tsas.ca/wp-content/uploads/2018/02/TSASWorking-Paper-Hofmann-Lone-Actors-Final.pdf $>$. See also Paul Gill, Lone-Actor Terrorists: A Behavioural Analysis (New York: Routledge, 2015); Mark S Hamm \& Ramón Spaaij, The Age of Lone Wolf Terrorism (New York: Columbia University Press, 2017).

131 See Joseph Tunney, “They Like to Talk': UNB Professor Challenges Concept of Lone-Wolf Terrorist," CBC News (13 February 2018), online: $<$ cbc.ca/news/canada/new-brunswick/unb-prof-challenges-lonewolf-stereotype-1.4532950>. For more, see Bart Schuurman et al, "End of the Lone Wolf: The Typology that Should Not Have Been” (2019) 42:8 Studies in Conflict \& Terrorism 771; Hofmann, ibid at 5.

$132 \quad$ Ali, supra note 11 at para 51.

133 R Kim Cragin \& Ari Weil, “Virtual Planners' in the Arsenal of Islamic State External Operations" (2018) 62:2 Orbis 294 at 300. 
group can include one person, who is both the actor and the entity. The Ali judgment turns that on its head - in part because it asserts that Parliament could have "create[d] an offence of committing an offence for a terrorist purpose." 134

In practice then, if the Crown's argument is rejected, as in Ali, an inspired lone wolf who commits an offence that otherwise meets all the criteria of terrorist activity - committed offence that causes death for a political, religious, or ideological purpose with the intention to intimidate the public - is not guilty of terrorism. Perhaps this outcome was a drafting or a conceptual error in that the drafters failed to criminalize terrorist activity directly, as the court in Ali suggested. But the Crown's case could also be seen to be more compelling in this scenario, because it can admit that the definitions are not perfectly worded or perhaps the drafting is sloppy, but surely the intention was not to legislate debates about lone wolf actors versus groups and then exclude from terrorism any accused's actions where the Crown has not proved beyond a reasonable doubt that the accused is not a lone wolf. According to the Crown then, the definition of terrorist group, and in turn entity, was always intended to cover lone actors; that is why the definition of "entity" is drafted both in the singular and plural. Drafting the definitions in this way was necessary because it is the only way that the Criminal Code, as structured, can overcome what would seem to be the glaring absence of other offences that might apply to lone wolves that engage in terrorist activity. The courts merely have to maintain a fidelity to the plain and ordinary meaning of the definition of terrorist activity, which in turn makes eminent sense when interpreted with a view to the construction of the Criminal Code's terrorism provisions as a whole - something not considered in the statutory interpretation in Ali - even if it seems clumsy when viewed in the context of section 83.2 as applied to lone wolf actors, which is how Justice MacDonnell preferred to analyze the definition.

There is another protection in place in the Criminal Code, which limits Justice MacDonnell's concerns, and it operates as follows. The Court in Ali did not agree that terrorist groups should be defined to include a single person in the context of section 83.2 if the accused and that single person - the group or entity — were one and the same. Such a definition produced a circularity with which the Court was not comfortable. The Court thus narrowed the scope of section 83.2 beyond section 83.2 's ordinary wording, which would only cover perpetrators who act on behalf of others. ${ }^{135}$ But as we have seen, the scope of the application of section 83.2 is limited to activity perpetrated in furtherance of a terrorist purpose because "terrorist group" must have as one or more of its purposes "terrorist activity." The phrase "terrorist activity" is thus doing the bulk of the work here, even if the legal drafting is awkward. What section 83.2 actually says, when applied, is that someone who commits a criminal offence that also meets the definition of terrorist activity-where that accused's purpose, motive, and consequences meet the definition - is guilty of a section 83.2 terrorism offence. Put another way, someone who tries to kill others in a way that meets the definition of terrorist activity can be found guilty of terrorism, in addition to attempted murder, even if that person acts alone. Viewed in light of the structure of the Part II.1

$134 \quad$ Ali, supra note 11 at para 75.

135 As the Court in Ali, supra note 11, stated at para 60: "The requirement that the underlying offence be committed "for the benefit of, at the direction of or in association with" a terrorist group supports an inference that Parliament did not intend that the person who committed the underlying offence in s. 83.2 and the entity for or with whom the offence was committed could be the same person." 
terrorism offences as a whole as reinforced by the plain wording of the definition of "entity," lone wolves should then be covered by section 83.2 even if the drafting of section 83.2 is awkward and would ordinarily apply to a situation where an accused is acting in association with a third party. As it stands, we have surely not seen the last of this debate, at least because of the appeal in Ali, and it is likely at some point that this interpretative issue will be resolved at the Supreme Court.

Let us thus move now to several things that Canadian courts have made very clear about the Criminal Code's definition of terrorist groups. First, even if a large associated group contains different sub-groups with different objectives, if any one of the sub-groups constitutes a terrorist group, then the entire organization also constitutes a terrorist entity. ${ }^{136}$ In the constitutional challenge brought by members of the Toronto 18, the Ontario Superior Court of Justice held that the word "activities" in subsection (a) should be given a purposive meaning. In practice, this means that "activities" should be read as "an action taken in pursuit of an objective." 137 The Court's interpretation here suggests that the group's activities should be undertaken with the purpose or objective of furthering terrorist activity. Hence, a group or organization that incidentally furthered terrorism in pursuing its objectives might not qualify as a terrorist group. For example, the Lafarge subsidiary in Syria that allegedly paid the Islamic State for the continued use of the company's cement plant in the country might not count as a terrorist group, because its activities were directed at pursuing a business opportunity. ${ }^{138}$

Second, a "listed entity" is an entity listed by the Governor in Council pursuant to section 83.05 where there are "reasonable grounds to believe" that the entity has (a) "knowingly carried out, attempted to carry out, participated in or facilitated a terrorist activity," or (b) is "knowingly act[ing] on behalf of, at the direction of or in association with [a listed entity]."139 Section 83.05 prescribes listing removal and review procedures, along with enshrining limited procedural fairness entitlements for listed entities, such as the right to notice and comment (after-the-fact), judicial review, redacted reasons, and a reasonable opportunity to be heard.

In practice, the listing does not actually allow the Crown to fully circumnavigate the definition of "terrorist activity." "140 The only offence-creating provisions that allow the Crown to rely on the terrorist entity listing without reference to the definition of "terrorist activity" are section 83.03(b) (providing, making available property or services for terrorist group), section 83.2 (commission of an indictable offence for a terrorist group), and the related offence found in section 83.201 (leaving Canada to commit an offence for a terrorist group).

Despite the limited practical significance of the terrorist entity listing, there are legitimate concerns regarding the constitutionality of the listing process, as the procedural fairness 
entitlements are thin. The process would in theory allow the Crown to substitute an executive decision for a judicial determination on an essential element of a criminal offence, which it has been argued violates section 11(d) of the Charter. ${ }^{141}$ The listing process has only ever been challenged in court in the context of a prosecution under section 83.18, where as noted above, the constitutionality issue (particularly that related to section 11(d) and the presumption of innocence) can be avoided. ${ }^{142}$ However, a 2012 report by the House of Commons' Standing Committee on Justice and Human Rights considered whether a listing process similar to that in section 83.05 should be adopted for criminal organizations. The Committee ultimately advised strongly against adopting such a listing process, in part due to constitutional concerns. ${ }^{143}$ As a result, there remains room for a constitutional challenge to cases founded on an accused's association with a listed terrorist entity.

With these predicates and definitions in mind, we now turn to the substantive offences that have been charged to date in terrorism trials in Canada. The first set of these, both sequentially as the first of the terrorism crimes in Part II.1 of the Criminal Code and as a basis for the first terrorism conviction in Canada, are the terrorism financing provisions.

The terrorism financing offences are found in sections 83.02, 83.03, and 83.04 of the Criminal Code. Broadly, the terrorism financing offences criminalize the following actions (actus reus): the collection, making available, or use of property, money, or financial or other services for terrorist purposes. The mens rea for each terrorism financing provision can generally be stated as follows: the accused must "intend" to finance terrorism or do so "with knowledge," both of which signify a high threshold for the Crown to meet. "Property" is defined in section 2 of the Criminal Code as including real and personal property, deeds, and other financial instruments. It is not self-evident whether "property" includes money. However, the various freezing, forfeiture, audit, and immunity provisions within Part II.1 refer only to "property," and the text of the provisions does not distinguish between money, financial services, or property. ${ }^{144}$ Hence, a purposive — and eminently practical interpretation of "property" in this context suggests that "property" includes money.

Roach has provided some guidance as to the distinction between these three terrorist financing provisions. He summarized the terrorist financing provisions as follows. First, section 83.02 is limited to the provision or collection of property intending or knowing that it will be used in whole or part for the commission of terrorist activities; it requires a high level of subjective fault, and would "not apply if the accused had a lawful justification."145 Second, section 83.03(a) creates a broader offence than section 83.02, as it applies not just to property but to "financial or other related services," and is extended to capture financing that benefits those who would in turn facilitate or carry out terrorist activity. Roach says that section 83.03(b) is broader yet because it requires no nexus to "terrorist activity" (within the

See David M Paciocco, "Constitutional Casualties of September 11: Limiting the Legacy of the AntiTerrorism Act" (2002) 16 SCLR 185 at 192-93. See also Craig Forcese \& Kent Roach, "Yesterday's Law: Terrorist Group Listing in Canada" (2018) 30:2 Terrorism \& Political Violence 259.

Hersi Constitutional Challenge, supra note 78 at para 21.

House of Commons, Standing Committee on Justice and Human Rights, The State of Organized Crime, 41-1 (March 2012) (Chair: Dave MacKenzie) at 19-22.

See e.g. Criminal Code, supra note 2, ss 83.08(1) (freezing of property), 83.08(2) (immunity from civil liability), 83.1(1)(a) (disclosure of the existence of property), 83.11 (audit provisions), 83.14(1) (forfeiture of property).

Roach, "Canada's New Anti-Terrorism Law," supra note 95 at 135. 
meaning of section 83.01) whatsoever. According to Roach, this breadth might bring in a relatively high level of subjective fault, which will in turn require that the Crown prove both that the accused "knew that the group [that the accused benefitted] was a terrorist group and that the group was a terrorist group." 146 Finally, Roach wrote that while section 83.04 does require a nexus to "terrorist activity," it does not require any overt act beyond the mere possession of property. This distinguishes section 83.04 from the other terrorist financing offences because those others require overt acts such as the use, collection, or provision of property or services. ${ }^{147}$

While that distinction suffices in broad brushstrokes, in the details the three terrorist financing provisions appear to overlap significantly, such that the same conduct could conceivably be captured under any of the three terrorism financing offences. For example, fertilizer is a common ingredient in homemade explosives, and it is a form of personal property, so it constitutes "property" within the meaning of section 2 of the Criminal Code. Consider then an individual who purchases fertilizer and provides it to another person, knowing and intending that the fertilizer will be used to create an explosive material for a bomb that will be detonated in a crowded public area for a terrorist purpose and motive. That individual can be said to have contravened all three of the terrorism financing offences, as he:

a. directly, willfully, and without lawful justification or excuse, provided property intending or knowing that it would be used in order to carry out an offence referred to in the International Convention for the Suppression of Terrorist Bombings, ${ }^{148}$ or would cause death or serious bodily harm to a civilian (section 83.02(a) and (b));

b. directly provided or made available property, intending or knowing that it would be used for the purpose of carrying out terrorist activity (section 83.03(a)); and

c. possessed property intending or knowing that it would be used for the purpose of carrying out terrorist activity (section 83.04(b)).

Hence, it does not appear that Parliament was attempting to create mutually exclusive, compartmentalized offences. Nor does it appear as if Parliament intended to create a graduated scale of increasingly culpable offences, as the maximum sentence for each financing provision is the same (ten years). It does look like the three terrorist financing provisions were drafted together as a hermetically sealed grab bag: while the distinction between the three can be debated, surely the three together seal off or capture any conceivable example of what one might think of as financing terrorism.

The problem with this approach is, first, that rather vague provisions that are hard to differentiate do not tend to serve the ends of justice particularly well; at best they simply create redundancies that clog up the Criminal Code. But, second, the situation is exacerbated in the context of terrorism prosecutions in Canada. As we shall see with the forthcoming 
discussion of sections 83.18 and 83.19 of the Criminal Code, a lack of differentiation between related offences can create difficulties when the Crown, not knowing which to charge, charges more than one count based on the same underlying actions (based on the same elements of the crime). ${ }^{149}$ Ordinarily such a situation would be resolved by the "Kienapple principle," whereby charges are stayed in one (lesser or equal) offence when it arises out of the "same delict" — the same facts and elements. ${ }^{150}$ However, as we shall see, courts thus far have circumvented the Kienapple principle in terrorism cases on rather specious grounds.

Unfortunately, judicial interpretations of these financing provisions remain limited. ${ }^{151}$ No charges have even been laid under sections 83.02 and 83.04. Section 83.03 (providing, making available, etc., property or services for terrorist purposes) has been challenged unsuccessfully for vagueness and overbreadth. ${ }^{152}$ There have been two convictions with reported decisions under section 83.03: one under section 83.03(a) (Khawaja), and the other under section 83.03(b) (Thambaithurai).

\section{B. OFFENCES}

1. SECTION 83.03(A)

a. Judicial Consideration

\begin{tabular}{|l|l|l|}
\hline \multirow{2}{*}{ 83.03(a) } & $\begin{array}{l}\text { Individuals charged under } \\
\text { 83.03(a): }\end{array}$ & $\begin{array}{l}\text { Trial judgments \& other decisions interpreting the } \\
\text { section: }\end{array}$ \\
\cline { 2 - 3 } & Momin Khawaja ${ }^{153}$ & R. v. Khawaja, 2008 CanLII 92005 (Ont Sup Ct J) \\
\hline
\end{tabular}

b. Criminal Code Provision

Providing, making available, etc., property or services for terrorist purposes

83.03 Every person is guilty of an indictable offence and liable to imprisonment for a term of not more than 10 years who, directly or indirectly, collects property, provides or invites a person to provide, or makes available property or financial or other related services

(a) intending that they be used, or knowing that they will be used, in whole or in part, for the purpose of facilitating or carrying out any terrorist activity, or for the purpose of benefiting any person who is facilitating or carrying out such an activity, or

(b) knowing that, in whole or part, they will be used by or will benefit a terrorist group. ${ }^{154}$

See the discussion below of sections 83.18 and 83.19 and the Kienapple Principle, below at 637-43. See Kienapple $v$ R, [1975] 1 SCR 729 at 745-48 [Kienapple].

For a discussion of why the financing provisions are rarely charged and the implications of this oversight, see Nesbitt, supra note 11 at 18-19.

Nadarajah ONSC, supra note 78 at para 22, aff'd Nadarajah ONCA, supra note 6.

Khawaja ONSC, supra note 12.

Criminal Code, supra note 2, s 83.03 [emphasis added]. 
Section 83.03(a) makes it an offence to provide, make available, or collect property or financial services intending or knowing that either: (1) it will "be used, in whole or in part, for the purpose of facilitating or carrying out any terrorist activity," or (2) it will benefit "any person who is facilitating or carrying out [terrorist] activity." ${ }^{155}$ Hence, in either case, this offence requires the trier of fact to find a nexus between the financing activity and terrorist activity and that the accused have knowledge of or intend for that nexus to be bridged.

The first prosecution under the terrorism financing provisions was in the Khawaja case. In that case, Momin Khawaja was charged and convicted under section 83.03(a) of the Criminal Code for offering up his parents' home in Pakistan for use by members of the UKbased terror cell, and to this end, he had directed his parents to evict their tenants. ${ }^{156}$ The Court noted that it did not matter that his parents' property was never used for its intended purpose, or that it was ultimately used by different people than he had intended — the actus reus of the offence is simply the making available of such property. ${ }^{157}$ The mens rea of the offence ${ }^{158}$ was satisfied in Khawaja simply by virtue of the fact that the "entire relationship" between the accused and the leader of the terrorist group involved the pursuit of their common objective of violent jihad; that is, the whole character of the relationship between the group and the motive sufficed to establish the requisite mens rea. ${ }^{159}$ On one hand, using the entire context to impute knowledge or intent is fairly common in Canadian criminal law; as such, this judicial finding is perfectly consistent with the normal (criminal) approach to proving the mens rea of intention or knowledge. On the other hand, courts ideally point to specific factors that denote an intention or knowledge, particularly because the mens rea must be proven beyond a reasonable doubt rather than just surmised — and intention and knowledge are higher thresholds than mere carelessness, meaning that it would serve as a defence to say that an accused was careless as to an outcome, but did not intend it (or have knowledge of it). Given that the ultimate use of the property was deemed irrelevant in Khawaja, the mens rea thus plays a key role as gatekeeper here between innocence and criminality, and courts should be very careful to ensure that the high mens rea threshold is met before convicting.

\section{SECTION 83.03(B)}

a. Judicial Consideration

\begin{tabular}{|l|l|l|}
\hline \multirow{8}{*}{ 83.03(b) } & $\begin{array}{l}\text { Individuals charged under } \\
\mathbf{8 3 . 0 3 ( b ) :}\end{array}$ & $\begin{array}{l}\text { Trial judgments \& other decisions interpreting the } \\
\text { section: }\end{array}$ \\
\cline { 2 - 3 } & Prapaharan Thambaithurai ${ }^{160}$ & $\begin{array}{l}\text { None. Thambaithurai pled guilty (see } R . v . \\
\text { Thambaithurai, 2010 BCSC 1949) }\end{array}$ \\
\hline
\end{tabular}

Ibid.

Khawaja ONSC, supra note 12 at para 136.

Ibid.

That Khawaja intended that the property be used, or knowing that it would be used, in whole or in part, for the purpose of facilitating or carrying out any terrorist activity, or for the purpose of benefiting any person who is facilitating or carrying out such an activity: s 83.03(a). Khawaja ONSC, supra note 12 at para 136.

Thambaithurai Trial, supra note 63. 


\section{b. Criminal Code Provision}

Providing, making available, etc., property or services for terrorist purposes

83.03 Every person is guilty of an indictable offence and is liable to imprisonment for a term of not more than 10 years who, directly or indirectly, collects property, provides or invites a person to provide, or makes available property or financial or other related services

(a) intending that they be used, or knowing that they will be used, in whole or in part, for the purpose of facilitating or carrying out any terrorist activity, or for the purpose of benefiting any person who is facilitating or carrying out such an activity, or

(b) knowing that, in whole or part, they will be used by or will benefit a terrorist group. ${ }^{161}$

Section 83.03(b) makes it an offence to provide, make available, or collect property or financial services knowing that it will be used, in whole or in part, by or for the benefit of a terrorist group. This is the only terrorism financing provision that does not require a nexus to terrorist activity. ${ }^{162}$ Canada's second terrorism financing prosecution proceeded under this provision, and it is the only other conviction for terrorist financing in Canada to date. For our purposes it is unfortunate that it arose out of a guilty plea to an offence under section 83.03(b) by Prapaharan Thambaithurai, because that meant that the Court did not pronounce on the elements of the offence. ${ }^{163}$ It was admitted in the case that up to half of the money he collected would go to the Liberation Tigers of Tamil Eelam, a listed terrorist entity. ${ }^{164}$ While the British Columbia Court of Appeal noted that "Mr. Thambaithurai's activities fell at the low end of the scale," he was ultimately sentenced to six months in prison. ${ }^{165}$

In the future, section 83.03(b) would seem to be vulnerable to constitutional challenge. Consider the elements of the offence in light of the Thambaithurai case. It is an offence to knowingly (mens rea) make available financial services to a terrorist group (actus reus). Now consider an individual who, like Mr. Thambaithurai, makes available funding to the Tamil Tigers. Since the Tamil Tigers are a listed entity, the Crown does not need to prove that the group was engaged in terrorist activity to meet the actus reus of section 83.03(b). All the Crown needs to show is that the group was listed and that the accused made the funds available, or sent them, to the group. The mens rea, that being "knowing" the funds will be used to benefit a terrorist group, is met since the accused knew he sent the money to the

Criminal Code, supra note 2, s 83.03(b) [emphasis added].

162 With the exception of section 83.02 (b), which in practice is probably co-extensive with terrorist activity. The mens rea of section 83.02(b) is the intentional causing of death or serious bodily harm to civilians in an armed conflict with the intention of intimidating the public or compelling a government or international organization (section 83.02(b)); this essentially describes violent insurgency without the explicit motive requirement per section 83.01(1)(b)(i)(A). Though, it is hard to imagine a situation where civilians are being targeted or governments are being compelled in the absence of a political, religious, or ideological motive. Therefore, in practice, the Crown could probably succeed in establishing a nexus to terrorist activity whenever section 83.02(b) is satisfied, leaving section 83.03(b) as the catch-all provision for financing activity that is directed towards purely peripheral terrorist group activity. Thambaithurai Trial, supra note 63 at para 2. Thambaithurai had collected two pledges for the World Tamil Movement, one in the amount of $\$ 600$ and the other in the amount of $\$ 300$. He wished to raise money for humanitarian aid for Tamil people in Sri Lanka who were victims of civil war and national disaster. 
Tigers. The Crown does not need to show the accused knew the group was listed. The accused's guilt should not depend on his knowledge of the law, including whether he knew the group was listed. Hersi, which considered the listing process though not its ultimate constitutionality, suggests that the accused would need to know at least that the Tigers engaged in terrorist activity. ${ }^{166}$ But Hersi is distinguishable here. Hersi was addressing section 83.18, which has the "ulterior intention" requirement. ${ }^{167}$ As we shall see, this requirement specifies that the accused must act for the purpose of furthering the listed entity's terrorist activities, something that is only convincingly shown when the Crown offers evidence the listed entity engaged in terrorism. Since section 83.03(b) lacks the ulterior intention requirement, both the mens rea and the actus reus for the provision can be proven without evidence before the court that the listed entity engaged in terrorist activities, or that the accused was ever aware the listed entity engaged in those activities.

The constitutional problem that arises for someone in Thambaithurai's position is evident: in the case of a listed entity, the element "terrorist group" as it features in the actus reus and mens rea of section 83.03(b) will seemingly be proven on a standard that falls short of "beyond a reasonable doubt." Listed entities, like the Tigers, are listed under the Criminal Code on a "reasonable grounds" basis, ${ }^{168}$ meaning that an individual in Thambaithurai's situation will be convicted on the basis that there are "reasonable grounds" to believe the entity to which he transferred money was a terrorist entity - a standard below the usual "beyond a reasonable doubt" standard of proof for criminal trials. The evidence that supported these "reasonable grounds" may not be before the court, though of course one supposes that complicated disclosure requirements may reveal the justification (the "reasonable grounds"). In the result, prosecutors should be wary of proceeding with a section 83.03(b) prosecution if they intend to rely on a listed terrorist entity as the basis for the charge — or at least they should be prepared to defend the constitutionality of the provision in such circumstances.

The prosecution may consider two approaches when dealing with a section 83.03(b) case where there is a concern about a constitutional challenge to the listing regime. First, they could argue that the "terrorist group" is not actually an element of the offence. The elements are knowingly (mens rea) and making available funds (actus reus). The reference to "terrorist group" in this instance plays much the same role as the "motive" requirement plays in the definition of "terrorist activity," that being a limiting role restricting the application of the offence. The courts should thus follow the logic of the Supreme Court in Khawaja in finding that "terrorist group," like motive as found in Khawaja, is not an element of the offence but a restrictive element that actually limits the application of the crime (knowingly making funds available). ${ }^{169}$ Second, the Crown can alternatively concede that "terrorist group" is an element of the offence and tender expert evidence on the listed entity's terrorist activity, as well as evidence showing the accused knew that the group was involved in terrorism. This was the approach taken in Hersi. ${ }^{170}$ Defence would nevertheless be well served to consider

166 Hersi Sentencing, supra note 11.

167 See the discussion below of the "ulterior intention" requirement in section 83.18 at pages 629-30 of this article.

168 See Criminal Code, supra note 2, s 83.05(1).

For an explanation of the motive element in the definition of "terrorist activity," see the above discussion in this article on page 611 . 
a constitutional challenge to the Criminal Code's terrorist listing regime (section 83.05) in these same circumstances by arguing that the guilt or innocence of the accused rises and falls on whether the group is a terrorist entity and, because the crime should be read as a whole - knowingly making funds available to a terrorist entity — the Crown must be required to prove all parts of that offence beyond a reasonable doubt. ${ }^{171}$ Moreover, even if the "terrorist group" requirement is seen as limiting, the "reasonable grounds" standard for listing actually works to increase the application of the offence to a greater number of groups by reducing the standard upon which a group may be labelled "terrorist." Finally, defence should argue that the funding of a "terrorist group" — as opposed to funding anyone — is really what makes this a wrongful act, and thus it is fundamental that "terrorist group" is proven beyond a reasonable doubt in court.

\section{PARTICIPATION IN ACTIVITY OF A \\ TERRORIST GROUP (SECTION 83.18)}

a. Judicial Interpretation

\begin{tabular}{|c|c|c|c|}
\hline \multirow{2}{*}{83.18} & \multicolumn{2}{|c|}{ Individuals charged under 83.18: } & $\begin{array}{l}\text { Trial judgments \& other decisions } \\
\text { interpreting the section: } \\
\text { R. v. Khawaja, } 2010 \text { ONCA } 862 \\
\text { R. v. Khawaja, } 2012 \text { SCC } 69 \\
\text { R. v. Khawaja, } 2008 \text { CanLII } 92005 \text { (Ont } \\
\text { Sun }\end{array}$ \\
\hline & $\begin{array}{l}\text { Shareef Abdelhaleem } \\
\text { Ibrahim Aboud } \\
\text { Fahim Ahmad } \\
\text { Misbahuddin Ahmed } \\
\text { Hiva Alizadeh } \\
\text { Zakaria Amara } \\
\text { Asad Ansari } \\
\text { Steven Chand } \\
\text { Mohammed Dirie } \\
\text { Amin Durrani } \\
\text { Chiheb Esseghaier } \\
\text { Saad Gaya } \\
\text { Ahmad Ghany } \\
\text { Mohamed Hersi } \\
\text { Qayyum Jamal } \\
\text { Jahmaal James } \\
\text { Raed Jaser }\end{array}$ & $\begin{array}{l}\text { Saad Khalid } \\
\text { Momin Khawaja } \\
\text { Ashton Larmond } \\
\text { Carlos Larmond } \\
\text { Manitoba Youth } \\
\text { Suliman Mohamed } \\
\text { Yasin Mohamed } \\
\text { Kevin Mohamed } \\
\text { Saïd Namouh } \\
\text { T18 Youth } 1 \\
\text { T18 Youth } 2 \\
\text { T18 Youth } 3 \\
\text { Nishanthan Yogakrishnan }\end{array}$ & $\begin{array}{l}\text { R. v. Khawaja, } 2010 \text { ONCA } 862 \\
R . v . \text { Khawaja, } 2012 \text { SCC } 69 \\
\text { R. v. Khawaja, } 2008 \text { CanLII } 92005 \text { (Ont } \\
\text { Sup Ct J) } \\
\text { R. v. Hersi, } 2014 \text { ONSC } 1217 \\
\text { R. v. NY, } 2008 \text { CanLII } 51935 \text { (Ont Sup Ct } \\
\text { J) } \\
\text { R. v. NY, } 2008 \text { CanLII } 24543 \text { (Ont Sup Ct } \\
\text { J) } \\
\text { R. v. Ansari, } 2015 \text { ONCA } 575 \\
\text { United States of America v. Nadarajah, } \\
\text { 2010 ONCA } 859 \\
\text { R. v. Ahmad, } 2009 \text { CanLII } 84774 \text { (Ont } \\
\text { Sup Ct J) } \\
\text { R. v. Nuttall, } 2016 \text { BCSC } 1404\end{array}$ \\
\hline
\end{tabular}

\section{b. Criminal Code Provision}

Participation in activity of a terrorist group

83.18 (1) Every one who knowingly participates in or contributes to, directly or indirectly, any activity of a terrorist group for the purpose of enhancing the ability of any terrorist group to facilitate or carry out a 
terrorist activity is guilty of an indictable offence and liable to imprisonment for a term of not more than 10 years. $^{172}$

Sequentially in the Criminal Code, the next terrorism offence is found in section 83.18, which applies to persons who contribute to or participate in the activities of what they know to be a terrorist group, and in doing so, they specifically intend to enhance the ability of that terrorist group to facilitate or carry out terrorist activity. ${ }^{173}$ This is a key provision because it has a relatively loose nexus to the definition of "terrorist activity," so it captures a broad range of conduct; this is borne out by the fact that, at the time of writing, section 83.18 is just ahead of section 83.2 as the most commonly charged terrorism offence under the Criminal Code.

Indeed, according to the Supreme Court in Khawaja, the purpose of section 83.18 is to prevent the "devastating harm that may result from terrorist activity" by criminalizing a wide range of actions "that have the potential to - and are intended to - materially enhance the abilities of terrorist groups." 174 This broad definition — and interpretation — has provoked a number of constitutional challenges on the grounds that section 83.18 creates an "inchoate upon inchoate" offence (discussed below). However, none of these challenges have succeeded, ${ }^{175}$ and in upholding the constitutionality of section 83.18 , courts have relied on — invented, really - two factors to temper this broad actus reus: (1) a de minimis threshold and (2) an elevated mens rea. ${ }^{176}$ These factors have been relied upon heavily in courts' findings that section 83.18 is not unconstitutionally overbroad, ${ }^{177}$ though they have also been the subject of much academic criticism. ${ }^{178}$

Criminal Code, supra note 2, s 83.18(1). Another important component is s 83.18(3), which reads: Participating in or contributing to an activity of a terrorist group includes

(a) providing, receiving or recruiting a person to receive training;

(b) providing or offering to provide a skill or an expertise for the benefit of, at the direction of or in association with a terrorist group;

(c) recruiting a person in order to facilitate or commit

(i) a terrorism offence, or

(ii) an act or omission outside Canada that, if committed in Canada, would be a terrorism offence;

(d) entering or remaining in any country for the benefit of, at the direction of or in association with a terrorist group; and

(e) making oneself, in response to instructions from any of the persons who constitute a terrorist group, available to facilitate or commit

(i) a terrorism offence, or

(ii) an act or omission outside Canada that, if committed in Canada, would be a terrorism offence.

Nadarajah ONCA, supra note 6 at para 28.

Khawaja SCC, supra note 76 at paras 62-63. See also Hersi Constitutional Challenge, supra note 78 at para 37.

Except in the Khawaja case in the first instance, but this was overturned upon appeal and that reversal was upheld at the Supreme Court of Canada.

Khawaja SCC, supra note 76 at para 62.

Ibid at paras 51-53; R $\vee$ Ansari, 2015 ONCA 575 at para 178 [Ansari ONCA]; Ahmad Constitutional Challenge, supra note 78 at para 44; Hersi Constitutional Challenge, supra note 78 at paras 24,30, 35-36, 41; Nadarajah ONCA, supra note 6 at para 23.

See e.g. Roach, "Be Careful What you Wish For," supra note 18; Hamish Stewart, "R. v. Khawaja: At the Limits of Fundamental Justice," (2013) 63 SCLR 403; Peter Sankoff, "Khawaja: Mixed Messages on the Meaning of Intention, Purpose and Desire," (2013) 97 CR (6th) 280. 


\section{INCHOATE UPON INCHOATE?}

Defence have challenged the constitutionality of section 83.18 on the basis that it is an "inchoate" offence based on an inchoate predicate. Section 83.18 is inchoate because it criminalizes acts that precede harmful conduct but do not necessarily inflict harmful consequences in and of themselves. ${ }^{179}$ The definition of "terrorist activity" includes conspiracies, attempts, counselling, and being an accessory after the fact, meaning that section 83.18 would stack an inchoate offence (a conspiracy or attempt) upon another inchoate offence (a preparatory act without a harm in the end). The Supreme Court of Canada held in the Déry case that inchoate upon inchoate offences, such as an attempt to conspire, are not sufficiently proximate to a substantive offence to warrant criminal sanction. ${ }^{180}$ However, when this "inchoate upon inchoate" argument was made before the Supreme Court of Canada in the Khawaja case, it was rejected on the grounds that Parliament defined the substantive offence not as a terrorist act but as "acting in ways that enhance the ability of a terrorist group to carry out a terrorist activity." "The Supreme Court emphasized that this interpretation reflects Parliament's determination that "there is substantive harm inherent in all aspects of preparation for a terrorist act because of the great harm that flows from the completion of terrorist acts." 182

Given the Supreme Court's decision, courts are unlikely to accept arguments on the basis that section 83.18 creates an inchoate offence. However, the Supreme Court did note that section 83.18 "captures a wide range of conduct," so defence counsel could still argue that the mens rea and actus reus requirements should be applied particularly stringently given the breadth of the offence. ${ }^{183}$

\section{ACTUS REUS OF SECTION 83.18:}

THE “DE MINIMIS” THRESHOLD

The Supreme Court in Khawaja held that the actus reus of section 83.18 requires that the Crown prove beyond a reasonable doubt that the accused, by his acts,

1. participated in or contributed to, directly or indirectly, any activity of a terrorist group; and

2. given the nature of the conduct and the relevant circumstances, a reasonable person would view the accused's acts as capable of materially enhancing the abilities of a terrorist group to facilitate or carry out a terrorist activity. ${ }^{184}$

The Ontario Court of Appeal confirmed in Nadarajah that the first requirement, above, includes participation in a non-terrorist activity of a terrorist group. ${ }^{185}$ Further, since the definition of terrorist activity includes a conspiracy, attempt, threat to commit, counselling,

\footnotetext{
$179 \quad R v$ Chan (2003), 66 OR (3d) 577 (CA), cited with approval in $R v$ Déry, 2006 SCC 53 [Déry].

180 Déry, ibid at paras 45-46.

$181 \quad$ Khawaja SCC, supra note 76 at para 61.

Ibid at para 63, citing Ahmad Constitutional Challenge, supra note 78 at para 60.

Khawaja SCC, ibid at para 62.

Ibid at paras 50-52.

Nadarajah ONCA, supra note 6 at para 20.
} 
or being an accessory after the fact, any direct or indirect contribution to a failed or futile attempt to commit terrorist activity would satisfy the actus reus of participation under section $83.18 .^{186}$

Section 83.18(4) enumerates factors that the trier of fact may consider in determining whether this first requirement (participation in a terrorist group) is made out, such as the use of identifying names, words, or symbols; frequent association with the group; receipt of a benefit; or repeatedly following the group's instructions. ${ }^{187}$ According to the Supreme Court, these factors do not expand the meaning of section 83.18 - section 83.18(3) simply allows the court to "consider" those factors in section 83.18(4). ${ }^{188}$ However, section $83.18(3)$ enumerates activities that automatically satisfy the actus reus of the offence, such as recruiting members or providing or receiving training. The Ontario Court of Appeal has clarified that section 83.18(3) does not expand the scope of section 83.18; rather, the enumerated activities are examples of activities that fall within the normal meaning of the provision. ${ }^{189}$ One trial judge described the section $83.18(3)$ enumerated activities as being essentially imperative, such that they "require" the trier of fact to conclude that the actus reus is made out "if [he finds] that [the accused] did one or more of the things mentioned in that provision." "190

The second requirement enumerated in Khawaja, above, is sometimes referred to as the “de minimis" threshold. ${ }^{191}$ This de minimis threshold arises not from the text of section 83.18, but from the Supreme Court's "purposive and contextual reading" of section 83.18 in Khawaja. ${ }^{192}$ The de minimis (material enhancement) threshold is the constitutional minimum to ensure that section 83.18 is not overbroad. ${ }^{193}$ Notably, this threshold appears nowhere in the text of section 83.18, so the Supreme Court's decision can be viewed as a rather heavyhanded reading down of the provision to avoid a finding of unconstitutional overbreadth. The Supreme Court justified reading in this requirement by observing that the length of the sentence (a maximum of ten years) and the serious stigma attached to the offence make it clear that Parliament did not intend for the provision to capture conduct that "creates no risk or a negligible risk of harm." 194

In justifying the reading-in of the de minimis threshold, the Supreme Court considered several hypothetical examples in its reasons for judgment. One such example put forward by the appellants was of a person who attends a visibility-enhancing event held by the charitable

Ibid at para 21.

Criminal Code, supra note 2, s 83.18(4) reads:

In determining whether an accused participates in or contributes to any activity of a terrorist group, the court may consider, among other factors, whether the accused

(a) uses a name, word, symbol or other representation that identifies, or is associated with, the terrorist group;

(b) frequently associates with any of the persons who constitute the terrorist group;

(c) receives any benefit from the terrorist group; or

(d) repeatedly engages in activities at the instruction of any of the persons who constitute the terrorist group.

Hersi Constitutional Challenge, supra note 78 at para 34.

Nadarajah ONCA, supra note 6 at para 18.

Ansari ONCA, supra note 177 at para 168.

Ibid at para 170; Nuttall Entrapment Application, supra note 11 at para 800.

Khawaja SCC, supra note 76 at para 51.

Ibid at paras 51-54; Ansari ONCA, supra note 177 at para 178.

Khawaja SCC, ibid at para 50. 
arm of a group that also engages in terrorist activity. ${ }^{195}$ The Supreme Court held that even if that person had the specific intent of lending credibility to the group and enhancing the group's ability to carry out terrorist activities, there could still be no conviction under section 83.18 as that conduct does not necessarily contribute to terrorism in any meaningful way. ${ }^{196}$ In that vein, the Supreme Court put forward the example of a restaurant owner who cooks a single meal for a known terrorist as not materially enhancing the abilities of the terrorist group. ${ }^{197}$ Roach raised another example: that lawyers and doctors employed by known terrorists may be captured by section $83.18 .{ }^{198}$ Here, the Supreme Court agreed that a conviction is theoretically possible, but only if the lawyer (or, mutatis mutandis, the doctor) held the requisite ulterior motive to enable the client to pursue further terrorist activities, as opposed to simply affording his client a full defence at law. ${ }^{199}$

A decision of the Ontario Court of Appeal in the Ansari case suggests that the activities enumerated in section $83.18(3)$ by their very nature exceed the de minimis threshold. ${ }^{200}$ However, it seems unlikely that a trier of fact could simply establish that, for example, an individual received training, and thereby completely bypass the de minimis (material enhancement) requirement. Surely it is plausible that an individual could receive training, but a reasonable person would not view that training as materially enhancing the ability of the group to facilitate or carry out terrorist activity. Nevertheless, in the $N Y$ case, the Ontario Superior Court of Justice described the accused youth's activities at the second of the Toronto 18 "training camps" as being "recreational and relatively benign," consisting largely of marching and hiking in military fatigues, with one agent describing the mood of the camp as "casual." "201 However, the Court nevertheless found that the youth's attendance at the Rockwood training camp sufficed to establish the actus reus of section 83.18 by virtue of being an activity enumerated under section $83.18(3)$.

It is not self-evident that a reasonable person would view participation in the Rockwood camp as materially enhancing that group's capacity to facilitate or carry out terrorist activity - and this is precisely the problem with the de minimis threshold, as applied here or elsewhere in criminal law. Simply put, what is de minimis is speculative and in the eye of the beholder; of course, this also makes it excellent grist for lawyers to plead their case, whether it be the defence arguing effectively that an accused's participation "didn't really matter" or a Crown arguing that certain participation could be seen as more consequential than it otherwise might appear. Respectfully, when the Court applied the section 83.18(3) enumerated factors in the $N Y$ case, thereby circumnavigating the de minimis threshold requirement, the resulting construction of section 83.18 may well have been unconstitutionally overbroad. There was no connection between the youth's presence at the camp and the benefit gained by — the enhancement to - the terrorist group. Put another way, statutory drafters could not have intended the section 83.18(3) enumerated factors to push participation beyond the de minimis threshold, because the Supreme Court had to invent the de minimis threshold to save the participation offence from the overbroad drafting. At the

\footnotetext{
$195 \quad$ Ibid at para 42.

$196 \quad$ Ibid at paras 49-54.

Ibid at para 52 .

Ibid at para 42, citing Roach, "New Terrorism Offences," supra note 5 at 161.

Khawaja SCC, ibid at para 47.

Ansari ONCA, supra note 177 at para 187.

NY Trial, supra note 12 at paras 106-23, 274-76.
} 
same time, there is nothing in the enumerated grounds that make them intrinsically consequential to meaningful participation - and such an argument has never been compellingly made, rather merely asserted in $N Y{ }^{202}$ Ultimately, the Court's holding in $N Y$ did not depend exclusively upon the presence of a section 83.18(3) enumerated activity. But defence counsel should be alive to the possibility that the presence of a section $83.18(3)$ enumerated activity may tempt a Court to bypass the de minimis threshold in a way that results in an unconstitutionally overbroad reading of section 83.18.

\section{MENS REA OF SECTION 83.18: "Ulterior INTENTION"}

The Supreme Court held in Khawaja that the mens rea of section 83.18 has two elements:

1. the accused must knowingly participate in or contribute to any activity of a terrorist group; ${ }^{203}$ and

2. his actions must be "undertaken 'for the purpose of' enhancing the abilities of a terrorist group to facilitate or carry out a terrorist activity."204

These two elements - knowingly and "for the purpose" - must be established even when the accused's acts fall under one of the activities listed in section $83.18(3),{ }^{205}$ or when one of the factors listed under section 83.18(4) is present, ${ }^{206}$ as neither section $83.18(3)$ nor section 83.18(4) diminishes the mens rea requirement. ${ }^{207}$ The second element - "for the purpose" - has been referred to by the Courts as the "ulterior intention" requirement. ${ }^{208}$

The Ontario Court of Appeal held in Nadarajah that an accused need not know the legal definition of "terrorist activity" in order to have the requisite ulterior intention, that is, to undertake actions for the purpose of enhancing the abilities of a terrorist group to facilitate or commit a terrorist act. Instead, an accused must simply have knowledge of the facts that would bring the activity to be facilitated or carried out within that definition, and intend for those facts to come about. ${ }^{209}$ According to the Supreme Court in Khawaja, the effect of the ulterior motive requirement is to exclude "mere negligent failure to take reasonable steps to avoid unwittingly assisting terrorists." 110 The Ontario Court of Appeal considered the example of a doctor providing free medical services to a hospital in Gaza being run by Hamas; even if the doctor knows that he is freeing up money that Hamas would otherwise

Ibid.

Supra note 76. The Supreme Court wrote at para 45 that "an individual must ... participate in or contribute to a terrorist activity "knowingly," ' but respectfully, this appears to be in error; section 83.18 prohibits the knowing participation or contribution in "any activity of a terrorist group" [emphasis in original].

Ibid at para 45 [emphasis in original]; Hersi Constitutional Challenge, supra note 78 at para 41.

Such as providing or receiving training (section 83.18(3)(a)), recruiting (section 83.18(3)(c)), or making oneself available to commit a terrorism offence (section 83.18(3)(e)).

Such as the use of an identifying name, word, or symbol (section 83.18(4)(a)); frequent association with the terrorist group (section 83.18(4)(b)); or receiving a benefit from the terrorist group (section $83.18(4)(\mathrm{c}))$.

Ahmad Constitutional Challenge, supra note 78 at para 45; NY Constitutional Challenge, supra note 78 at para 9.

Hersi Constitutional Challenge, supra note 78 at para 36; Nadarajah ONCA, supra note 6 at para 23. Nadarajah ONCA, ibid at para 24.

Khawaja SCC, supra note 76 at para 47, citing Roach, “Terrorism Offences and the Charter," supra note 102 at 286. 
spend paying medical workers, money which could instead be used to amass bombs to target innocent civilians, the Court held that in such circumstances the ulterior motive would still not be satisfied because his medical assistance is not for the purpose of enhancing Hamas' capacity for terrorist activity. ${ }^{211}$ As a result, "for the purpose" is read as a high mens rea threshold.

But, section 83.18(2)(a) also makes clear that the mens rea might be satisfied regardless of whether or not any terrorist activity was actually facilitated or carried out. ${ }^{212}$ Thus, the mens rea of the offence might still be made out even if the terrorist group's plot or plans never come to fruition. The specific nature of the terrorist activity, such as the death of a person from a bombing, need not be intended, ${ }^{213}$ the accused must simply intend in a general sense that his acts enhance the ability of the terrorist group to carry out or facilitate a terrorist activity. ${ }^{214}$ This means that even the "smaller guys" in a group who may not know the specifics of a plot may nonetheless possess the requisite mens rea. ${ }^{215}$

\section{LEAVING CANADA TO PARTICIPATE IN ACTIVITY OF TERRORIST GROUP (SECTION 83.181)}

a. Judicial Consideration

\begin{tabular}{|l|l|l|}
\hline $\mathbf{8 3 . 1 8 1}$ & $\begin{array}{l}\text { Individuals charged under } \\
\mathbf{8 3 . 1 8 1 :}\end{array}$ & $\begin{array}{l}\text { Trial judgments \& other decisions interpreting the } \\
\text { section: }\end{array}$ \\
\cline { 2 - 3 } & $\begin{array}{l}\text { Ismaël Habib } \\
\text { Carlos Larmond } \\
\text { Alberta Youth } \\
\text { Quebec Youth [LSJPA] } \\
\text { Sabrine Djermane } \\
\text { El Mahdi Jamali }\end{array}$ & $\begin{array}{l}\text { R. Habib, 2017 QCCQ 11427 } \\
\text { See also } \text { R. v. Hersi, 2014 ONSC 4414 (charged under } \\
\text { section 83.18, but the idea was that he was attempting } \\
\text { to travel to participate in a terrorist activity) }\end{array}$ \\
\hline
\end{tabular}

\section{b. Criminal Code Provision}

Leaving Canada to participate in activity of terrorist group

83.181 Every person who leaves or attempts to leave Canada, or goes or attempts to go on board a conveyance with the intent to leave Canada, for the purpose of committing an act or omission outside Canada that, if committed in Canada, would be an offence under subsection 83.18(1) is guilty of an indictable offence and liable to imprisonment for a term of not more than 10 years. ${ }^{216}$

Section 83.181 of the Criminal Code makes it an offence to leave or attempt to leave Canada with the intent of committing acts outside of Canada that would constitute an offence under section 83.18 (participation in activity of terrorist group). Although section 83.181 is

Hersi Constitutional Challenge, supra note 78 at para 40.

Criminal Code, supra note 2, s 83.18(2)(a).

Ibid, s 83.18(2)(c).

Khawaja SCC, supra note 76 at para 46.

NY Trial, supra note 12 at para 251.

Criminal Code, supra note 2, s 83.181. 
the fourth most commonly charged terrorism offence since 2001, this provision only dates to 2013; it was added (along with the other terrorist travel provisions) ${ }^{217}$ by virtue of the 2013 Combating Terrorism Act. ${ }^{218}$ These amendments were enacted in response to increasing Internet youth recruitment programs by extremist groups such as Al-Shabaab, a listed terrorist group based in Somalia. ${ }^{219}$

The new provisions, including section 83.181 , were intended to create offences that were "specifically tailored" to terrorist travel, but terrorist travel was already captured under the original Anti-Terrorism Act (2001) provisions. For example, Mohamed Hersi was intercepted and arrested at the Toronto Pearson Airport while attempting to leave Canada to travel to Somalia (via Egypt) and join Al-Shabaab. ${ }^{220} \mathrm{He}$ was charged and convicted with both attempting and counselling participation in the activities of a terrorist group under section 83.18. ${ }^{221}$ Nevertheless, Parliament wanted an offence that was more direct - and that sent a message more directly and clearly that traveling for a terrorist purpose was a crime to be taken seriously. ${ }^{222}$

The actus reus of this offence is the act of "leav[ing]" or "attempt[ing] to leave Canada," or "attempt[ing] to go on board a conveyance with the intent to leave Canada." 223 This provision has not yet been considered by the Supreme Court, nor has its constitutionality been challenged; however, the Court of Quebec held in a case concerning a radicalized youth that an attempt to purchase a plane ticket to Gaziantep, Turkey - a border-town frequently used by the Islamic State and others as an point of entry into Syria - sufficed to establish the actus reus of this offence. 224

Hence, much like the participation offence under section 83.18, the actus reus of this offence can be satisfied by seemingly benign activities, but it is offset by an elevated mens rea requirement. The Court of Quebec held in Habib that the mens rea of this offence is twofold: the Crown must prove (1) the primary attempt to leave Canada and (2) the specific intent to commit an offence under section 83.18. ${ }^{225}$ The Court of Quebec emphasized in the LSJPA - 1557 youth terrorism prosecution that the second requirement of specific intent is critical, as it is not the act of buying a plane ticket that is illegal — it is the accompanying specific intent that renders that act unlawful. ${ }^{226}$

The mens rea is therefore inherited from section 83.18; that is, the evidence must establish that the accused attempted to leave Canada "with the intent to knowingly participate in or

Sections 83.191 (leaving Canada to facilitate terrorist activity), 83.201 (leaving Canada to commit offence for terrorist group), and 83.202 (leaving Canada to commit offence that is terrorist activity). Supra note 4, ss 6-8.

Debates of the Senate, 41-1, vol 148, No 55 (29 February 2012) at 1500 (Hon Linda Frum); House of Commons Debates, 41-1, vol 146, No 161 (15 October 2012) at 1210 (Kerry-Lynne D Findlay).

Hersi Sentencing, supra note 11 at para 3.

Ibid.

The need for Criminal Code provisions that clearly and directly condemn terrorist travel was reiterated several times during Parliamentary debates over the passage of the bill. See Kerry-Lynne D Findlay's remarks, supra note 219; House of Commons Debates, 41-1, vol 146, No 237 (22 April 2013) at 1200 (Candice Bergen); House of Commons Debates, 41-1, vol 146, No 250 (9 May 2013) at 1340 (Candice Bergen).

Criminal Code, supra note 2, s 83.181.

LSJPA - 1557, supra note 11 at para 288.

Habib Trial, supra note 75 at para 56.

LSJPA - 1557, supra note 11 at para 287. 
contribute to a terrorist activity, to carry out a terrorist activity or to facilitate its commission." 227 Similarly, the ulterior motive requirement from section 83.18 would also be inherited by section 83.181 , such that the trier of fact would have to find that the accused intended to travel to commit acts "for the purpose" of enhancing the abilities of a terrorist group to facilitate or carry out a terrorist activity." 228 The evidence must establish, when taken as a whole, that the accused's desire to leave Canada to participate in the activity of a terrorist group is not hypothetical or a whim, ${ }^{229}$ which of course leaves room for courtroom debate regarding the extent to which an accused's intentions had really coalesced into something meaningful (or non-whimsical).

Given that the mens rea of this offence - the element that does the most "work" - is inherited from the thoroughly adjudicated section 83.18 , the actual elements of the section 83.181 terrorist travel offence are likely on solid constitutional footing based on existing Supreme Court and Court of Appeal jurisprudence. Rather, the problem for the Crown - and where a defence lawyer is more likely to successfully lay her hat - will be around establishing the accused's specific intent to commit an offence under section 83.181. In the case of LSJPA-1557, the Crown was fortunate to have extensive Twitter correspondence between the youth accused and another suspected terrorist, ${ }^{230}$ such that within that correspondence, the youth accused made numerous enquiries and statements regarding his extremist travel plans. ${ }^{231}$ In the terrorism trial of Ismaël Habib, the Crown had to rely on a statement made to an undercover officer in the context of a Mr. Big operation regarding his intentions to return to Syria to join the Islamic State, despite the fact that the accused had already made one trip to Syria ostensibly for the purpose of pursuing violent jihad. ${ }^{232}$

We can only speculate as to why Habib was not also charged with respect to the first trip to Syria. In general, the prosecution may run into issues in seeking to rely upon evidence regarding the accused's activities while abroad because of the so-called "intelligence-toevidence" problem. In particular, intelligence obtained from foreign entities may not meet the standard of reliability required by Canadian courts, particularly where there is reason to believe that the intelligence was derived from torture, where it comes from hearsay of a third party, or where it is based on intelligence techniques that cannot be explained in court. ${ }^{233}$ Thus, prosecutors may have to find other sources of evidence to establish the accused's specific intent to commit an offence under section 83.181 , or they could do as the prosecutors in LSJPA-1557 and Habib did and rely upon statements made by the accused, though that may bring about problems with proving that electronic — online — statements were both made by the accused (authentication) and are accurate statements about the intentions of the accused.

Habib Trial, supra note 75 at para 56 [emphasis added].

Khawaja SCC, supra note 76 at para 45.

Habib Trial, supra note 75 at para 68; Hersi Sentencing, supra note 11 at paras $40-41$.

Martin Couture-Rouleau, who would go on to strike two RCMP members in a vehicular attack in October 2014 in St-Jean-sur-Richelieu, Quebec, injuring one officer and killing the other: LSJPA-1557, supra note 11 at para 142 .

LSJPA-1557, ibid at paras 297-301.

Habib Trial, supra note 75 at para 45.

For more information on the intelligence-to-evidence problem, see in general: West, supra note 15; Roach, "Unique Challenges," supra note 15; Roach \& Forcese, "Intelligence to Evidence," supra note 15 . 
We have already seen one terrorism prosecution in Canada fall apart because of the errors made in the collection of electronic evidence. In Hamdan, the accused was found not guilty of instructing others to carry out terrorism (section 83.22) in large part because investigators merely took screenshots of his Facebook posts, which would seem to have advocated terrorism, but he was able to argue that they provided an inaccurate snapshot of what was a longer and more complex conversation online. The posts were, in other words, taken out of context. $^{234}$

These sorts of evidentiary problems - not to mention the complex intelligence-toevidence problems associated with acquiring information of someone's activities abroad and using them in a court of law — are likely to cause the primary hurdles in successful prosecutions under section 83.181 going forward, in part because the whole case turns on the accused's intentions in traveling and not on the act itself. ${ }^{235}$

\section{FACILITATING Terrorist ACTIVITy (SECTION 83.19)}

\section{a. Judicial Consideration}

\begin{tabular}{|c|c|c|}
\hline \multirow{2}{*}{83.19} & $\begin{array}{l}\text { Individuals charged under } \\
\text { 83.19: }\end{array}$ & $\begin{array}{l}\text { Trial judgments \& other decisions interpreting the } \\
\text { section: }\end{array}$ \\
\hline & $\begin{array}{l}\text { Misbahuddin Ahmed } \\
\text { Hiva Alizadeh } \\
\text { Sabrine Djermane } \\
\text { El Mahdi Jamali } \\
\text { Momin Khawaja } \\
\text { Amanda Korody } \\
\text { Ashton Larmond } \\
\text { Saïd Namouh } \\
\text { John Nuttall } \\
\text { Khurram Syed Sher }\end{array}$ & $\begin{array}{l}\text { R. v. Ahmad, } 2009 \text { CanLII } 84774 \text { (Ont Sup Ct J) } \\
\text { R. v. Ahmed, } 2014 \text { ONSC } 6153 \\
\text { R. v. Ahmed, } 2017 \text { ONCA } 76 \\
\text { R. v. Khawaja, } 2008 \text { CanLII } 92005 \text { (Ont Sup Ct J) } \\
\text { R. v. Khawaja, } 2010 \text { ONCA } 862 \\
\text { R. v. Khawaja, } 2012 \text { SCC } 69 \\
\text { United States of America v. Nadarajah, } 2010 \text { ONCA } \\
859 \\
\text { R. v. Namouh, } 2009 \text { QCCQ } 9324 \\
\text { R. v. Namouh, } 2010 \text { QCCQ } 943 \\
\text { R. v. Nuttall, } 2015 \text { BCSC } 943 \\
\text { R. v. Nuttall, } 2016 \text { BCSC } 1404 \\
\text { R. v. Sher, } 2014 \text { ONSC } 4790\end{array}$ \\
\hline
\end{tabular}

Hamdan Trial, supra note 11 at paras 140-43, 191-94.

The Minister of Public Safety, Ralph Goodale, explained in 2017 that part of Canada's failure to prosecute terrorist travellers arose from challenges in converting intelligence to evidence: Rachel Gilmore, "Canada Struggling to Prosecute Returned ISIS Fighters," iPolitics (26 November 2017), online: $<$ ipolitics.ca/2017/11/26/canada-struggling-prosecute-returned-daesh-fighters/>. For a recent discussions of Canada's intelligence-to-evidence framework and its shortcomings, see West, supra note 15; Craig Forcese, "Threading the Needle: Structural Reform \& Canada's Intelligence-to-Evidence Dilemma," (2018) University of Ottawa Working Paper No 2018-19, online: <papers.ssrn.com/sol3/ papers.cfm?abstract id $=3214750>$. As well, see the following article for a discussion of the challenges, evidentiary and otherwise, that arise in prosecuting foreign fighters: Craig Forcese \& Ani Mamikon, "Neutrality Law, Anti-Terrorism, and Foreign Fighters: Legal Solutions To The Recruitment Of Canadians To Foreign Insurgencies," (2015) 48:2 UBC L Rev 305 at 323-32. 


\section{b. Criminal Code Provision}

Facilitating terrorist activity

83.19 (1) Every one who knowingly facilitates a terrorist activity is guilty of an indictable offence and liable to imprisonment for a term not exceeding fourteen years.

Facilitation

(2) For the purposes of this Part, a terrorist activity is facilitated whether or not

(a) the facilitator knows that a particular terrorist activity is facilitated;

(b) any particular terrorist activity was foreseen or planned at the time it was facilitated; or

(c) any terrorist activity was actually carried out. ${ }^{236}$

Section 83.19 makes it an offence to knowingly facilitate terrorist activity, regardless of the extent of the facilitator's knowledge or foresight of the facilitated terrorist activity, and even regardless of whether any terrorist activity was ultimately carried out. ${ }^{237}$ In the Nuttall case, the Supreme Court of British Columbia held that the facilitation offence is meant to capture persons who are on the periphery of terrorist groups and activities where the Crown cannot prove "knowledge of the specific terrorist activity involved," but the accused nevertheless aided in carrying out the acts. ${ }^{238}$ This section is the only one of the five most commonly charged terrorism offences that does not require the Crown to establish the existence of a terrorist group, although the Crown must nonetheless prove the existence of terrorist activity.

\section{ACtUS REUS OF SECTION 83.19: "MAKE EASY OR EASIER"}

"Facilitation" is not defined in the Criminal Code. However, in the R. v. Lindsay case, the Ontario Court of Appeal contemplated the meaning of "facilitation" within the meaning of the criminal organization provisions of the Criminal Code. ${ }^{239}$ The Court held in that case that a dictionary meaning of "facilitation" is appropriate because the term is common and well understood in both ordinary and legal parlance. ${ }^{240}$ The Court endorsed "to make easy or easier" as a definition of "facilitate." 241 This definition was subsequently adopted by the British Columbia Court of Appeal in R. v. Kwok, again in the criminal organization context. $^{242}$

The Supreme Court of British Columbia in Nuttall noted that the Part II.1 terrorism provisions mirror the criminal organization provisions, and that they were meant to have similarly preventive functions. The Court thus extended the "make easy or easier" definition

\footnotetext{
236 Criminal Code, supra note 2, s 83.19.

237 Ibid.

$238 \quad R v$ Nuttall, 2015 BCSC 943 at para 94 [Nuttall Directed Verdict].

$239 R$ v Lindsay, 2009 ONCA 532 at para 23.

240 Ibid.

241 Ibid, citing Concise Oxford English Dictionary, supra note 137, sub verbo "facilitate."

$242 \quad R v$ Kwok, 2015 BCCA 34 at para 86.
} 
of facilitation used in criminal organization offences (under section 467.1(1)) to the context of section $83.19 .{ }^{243}$ Consequently, the Court in Nuttall concluded that section 83.19 is not intended to punish principal offenders who actually commit the terrorist activity; rather, principal offenders should be charged under section 83.2 (discussed below). ${ }^{244}$ The actus reus of section 83.19 merely requires the accused to make the carrying out of terrorist activity by a principal "easy or easier."

Section 83.19(2)(c) of the Criminal Code extends the definition of facilitation to any activity that is "facilitated" regardless of whether or not any terrorist activity was actually carried out. ${ }^{245}$ This appears to expand the ambit of the facilitation offence to include terrorist plots that were not ultimately carried out. But it is also consistent with judicial interpretations of financing and participation provisions we have seen in this article, as well as the instructing terrorist activity provision (section 83.22 , discussed below) ${ }^{246}$ in that the judiciary is adamant that pre-emptive (pre-violence) terrorism offences do not require the Crown to prove what was going to happen or was likely to happen in the future.

The definition of "terrorist activity" also, it will be recalled, includes a conspiracy, attempt, threat to commit, counselling or being an accessory after the fact to terrorist activity, ${ }^{247}$ which according to the Ontario Court of Appeal in Nadarajah has the effect of expanding the facilitation offence to capture plots that were "failed" or "futile." 248 Putting together these two extensions of what it means to facilitate a terrorist plot, the result is that an individual could be convicted of facilitating terrorist activity where he makes it "easier" to perpetrate a futile plot that was, in any event, never really going to come to pass. ${ }^{249}$

In the result, although the purpose of the Part II.1 terrorism provisions is to prevent acts of terrorism, ${ }^{250}$ criminalizing the facilitation of fictional terror plots surely overshoots even this broad statutory objective. Nevertheless, the constitutionality of section 83.19 was only challenged in the Toronto 18 proceedings with respect to the extended definition of facilitation (section 83.19(2)) as it applies in the context of the participation offence under section 83.18 , rather than a challenge of the facilitation offence itself. ${ }^{251}$ Thus, the facilitation offence under section 83.19(1) has never been directly challenged for overbreadth in court, and even if such challenges rarely succeed, ${ }^{252}$ this drafting is ripe for further judicial clarification. If section 83.19(2)(c) was indeed intended to extend the definition of "facilitation" to include failed and especially futile plots, such an interpretation is already

243 Nuttall Directed Verdict, supra note 238 at paras 83-87. Justice Rutherford adopted a similar definition from the Shorter Oxford English Dictionary in the Khawaja trial, "to render easier, to promote, help forward, assist": Khawaja ONSC, supra note 12 at para 138, aff'd Khawaja ONCA, supra note 52; Khawaja SCC, supra note 76.

$244 \quad$ Nuttall Directed Verdict, ibid at para 94.

245 Criminal Code, supra note 2, s 83.19(2)(c).

246 See below at pages 645-47.

247 Criminal Code, supra note 2, s 83.01(1)(b)(ii).

248 Nadarajah ONCA, supra note 6 at para 21, in the context of the participation in the activity of a terrorist group offence under section 83.18 .

249 Note that the extended definition of "facilitation" in section 83.19(2) applies throughout Part II.1.

$250 \quad$ Khawaja SCC, supra note 76 at para 63; Nadarajah ONCA, supra note 6 at paras 32-35; Ahmad Constitutional Challenge, supra note 78 at paras 67-71.

251 Ahmad Constitutional Challenge, ibid at paras 1-4. Note that the concluding paragraph stating that section 83.19 does "not violate ss. 2 or 7 of the Charter" thus only refers to section $83.19(2)$, rather than the offence-creating provision (section 83.19(1)): Ahmad Constitutional Challenge, ibid at para 142. Roach, "Canada's New Anti-Terrorism Law," supra note 95 at 147. 
captured by the inchoate activity included in the definition of "terrorist activity." In the result, while a constitutional challenge may not succeed in overturning the section 83.19 facilitation offence, it could result in the right case (one with a fictional, futile plot) in a reading down of the extended definition of "facilitation" to exclude section 83.19(2)(c), just as the breadth of section 83.18 has been "read down" by the Supreme Court in Khawaja, as discussed above. ${ }^{253}$

\section{MENS REA OF SECTION 83.19: "KNOWINGLY FACILITATING"}

The mens rea element of section 83.19 is the knowing facilitation of terrorist activity. ${ }^{254}$ This is in contrast with section $83.18,{ }^{255}$ wherein the accused must have specifically intended the carrying out of terrorist activity. ${ }^{256}$ The expanded definition of facilitation in section 83.19 (2) provides that the accused need not know that a particular terrorist activity is facilitated or was foreseen or planned at the time it was facilitated:

For the purposes of this Part, a terrorist activity is facilitated whether or not

(a) the facilitator knows that a particular terrorist activity is facilitated;

(b) any particular terrorist activity was foreseen or planned at the time it was facilitated; or

(c) any terrorist activity was actually carried out. ${ }^{257}$

This extended definition distinguishes the facilitation offence from a traditional aiding and abetting offence, where the aider (or abettor) must know that the perpetrator intends to commit that specific crime, although he "need not know precisely how it will be committed." 258 Indeed, when the Anti-Terrorism Act (2001) was in the Special Senate Committee, witness Donald Piragoff, then Senior General Counsel in the Criminal Law Policy section of the Department of Justice, testified that the extended definition of "facilitation" under section 83.19(2) was meant to distinguish facilitation from aiding and abetting:

The senator pointed out that a terrorist activity may be facilitated whether or not the facilitator knows that a particular terrorist activity is facilitated or whether the terrorist activity was actually carried out. That is meant to resolve a problem in the current Criminal Code in the existing offences of aiding and abetting where you have to actually know of the specific offence that you are aiding and abetting. ${ }^{259}$

Rather, the extended definition of facilitation is intended to capture those who are out-ofthe-know and operate on the fringe of terrorist plots:

This particular provision is trying to capture the situation where a person knows that he or she is assisting a terrorist group by providing false documents but does not know that on September 11 the World Trade Center

253 See above at page 627.

$254 \quad$ Nuttall Directed Verdict, supra note 238 at para 91.

255 Ibid.

$256 \quad$ Namouh Trial, supra note 75 at para 68.

257 Criminal Code, supra note 2, s 83.19(2).

$258 \quad R v$ Briscoe, 2010 SCC 13 at para 17; $R$ v Hibbert, [1995] 2 SCR 973 at para 38.

259 Senate, Special Senate Committee on the Subject Matter of Bill C-36, Proceedings, $37-1$ (22 October 2001) at 1:51 (Donald Piragoff) [emphasis added]. 
will be bombed and that these documents are being [provided] for the purpose of getting people into the United States illegally, for example. That is the notion of facilitating. You know you are helping them. You do not know exactly what particular crime is going to be committed but you know something bad will be done. $^{260}$

In short, the knowledge requirement for facilitation of terrorist activity under section 83.19 is intended to be generalized, rather than specific; one must know generally that something that could constitute terrorism is in the offing, not specifically what is planned. Roach has noted that the extended definition of facilitation "goes beyond watering down the fault element to obliterating it," as it seems impossible to knowingly facilitate a terrorist activity "when you do not know that "any particular terrorist activity was foreseen or planned at the time it was facilitated." ${ }^{261}$ Simply put, it is hard to reconcile potentially non-existent terrorist activity with the requirement to knowingly facilitate terrorist activity. Moreover, the extended definition of facilitation would on the court's reading (possibly) require a lower threshold mens rea than that required for the participation offence (knowingly facilitating an unknown terrorist activity versus specifically intending to support an unknown terrorist group). But the terms of incarceration for facilitation is a maximum of 14 years in jail, as opposed to ten years for the participation offence. The seriousness of the offences, as signalled by the available punishments and the Criminal Code's planned escalation of culpability from section 83.18 (ten years) to section 83.19 (14 years) to section 83.2 (life), would militate in favour of a lower mens rea threshold for participation, not facilitation. The penalty of facilitation as opposed to participation, in other words, does not tend to support the judicial interpretation of the scope of section 83.18 as compared to section 83.19 . As such, section 83.19(2)'s extended definition of "terrorist activity" once again calls out for further judicial interpretation, and remains ripe for constitutional challenge for lacking the constitutional minimum mens rea for such a serious and stigmatizing offence. As we have seen with other offences, the outcome is unlikely to rule section 83.19 unconstitutional. Rather, as with section 83.18 , current judicial trends in terrorist prosecutions would suggest that the courts will minimize the scope of the section 83.19 offence at most.

\section{1. (FURTHER) ELIDING THE DisTINCTION BETWEEN SECTIONS 83.18 AND 83.19}

The offences of participation in the activity of a terrorist group (section 83.18) and facilitation of a terrorist activity (section 83.19) can both be briefly summarized as capturing peripheral assistance or facilitation of acts of terrorism. However, Parliament enacted them as separate offences, and the drafting contains two distinctions:

1. section 83.19 only refers to "terrorist activity," whereas section 83.18 refers to both "terrorist group" and "terrorist activity",262 and offences linked to "terrorist activity" and those offences linked to the definition of "terrorist group": Forcese, National Security Law, supra note 2 at 284. 
2. section 83.19 requires that the impugned conduct facilitated terrorist activity, whereas section 83.18 encompasses participation in or contribution to "any activity of a terrorist group," not just terrorist activity, though of course the Supreme Court in Khawaja has introduced a de minimis threshold for such participation or contribution.

Thus, in broad strokes, the distinction apparent from the drafting appears to be that section 83.18 encompasses both capacity-building activities and direct contributions to a terrorist group, whereas section 83.19 requires direct contribution to a terrorist plot - which, again, has been interpreted to include contribution to a plot that is not known in the specifics to the accused. The section 83.18 participation offence is thus, in theory, less serious than the section 83.19 facilitation offence, at least in that the maximum punishment is lower.

The following chart compares how often the sections were charged separately and together, and the number of convictions that have resulted in each circumstance: ${ }^{263}$

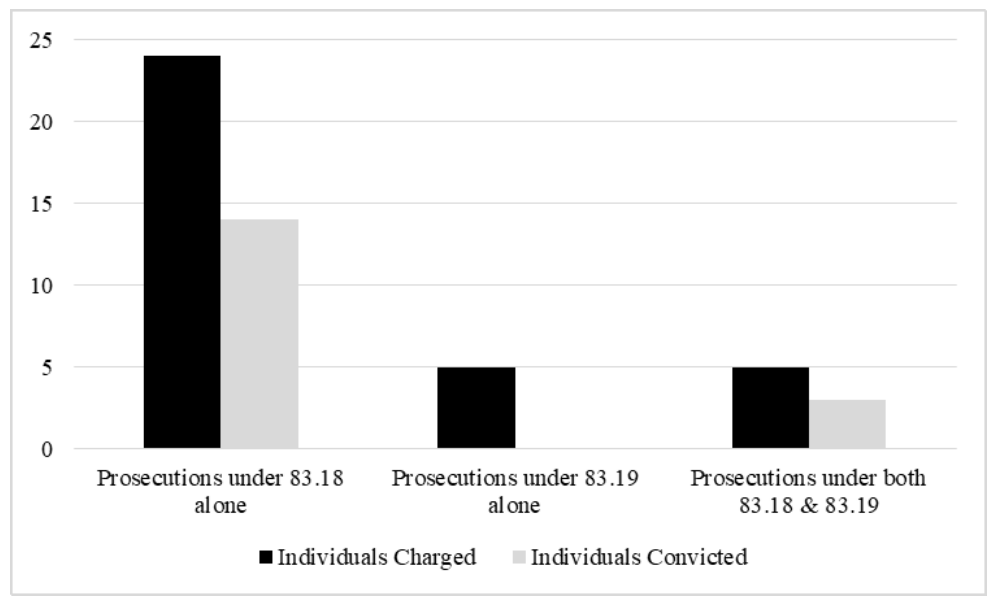

The chart shows that sections 83.18 and 83.19 are infrequently charged together. Prosecutors have charged only five individuals with both sections simultaneously: Hiva Alizadeh, Ashton Larmond, Momin Khawaja, Saïd Namouh, and Misbahuddin Ahmed. ${ }^{264}$

The overlap between the provisions meant in the Khawaja case, that the count under section 83.19 was treated as a "basket charge." 265 The Crown did not particularize the charge in the indictment in Khawaja, so it was used as a catch-all for the activities that had not yet been accounted for under the prior six counts, such as Khawaja transporting money, a medical kit, SIM cards, and invisible ink pens; offering to purchase night-vision goggles; inviting members of the group to come to Canada for shooting practice; and so forth. ${ }^{266} \mathrm{As}$ of the applicable cases, see Nesbitt, supra note 11 at 16-17. 11; Alizadeh Sentencing, supra note 32; Larmond, supra note 54. 
a result, the trial judge noted that section 83.19 "could overlap virtually all [of] the previous 6 counts," including the charges under sections 83.03 (making available property for terrorist purposes), 83.18 (participation in activity of terrorist group), 83.2 (commission of offence for terrorist group), and 83.21 (instructing to carry out activity for terrorist group). ${ }^{267}$ Despite this perceived overlap, the judge accepted the Crown's seemingly arbitrary division of activities, and imposed separate sentences under both section 83.18 and section 83.19, although the sentence under section 83.19 was shortened to reflect his view that it "overlap[s] significantly with the facts underlying the other counts."268

In Namouh, the Court of Quebec held that the accused's creation and distribution of videos through an al-Qaeda-affiliated website (the Global Islamic Media Front) was sufficient to convict under both sections 83.18 and 83.19. ${ }^{269}$ The same activity — or actus reus - was the basis for both convictions. Indeed, the Court's analysis does not meaningfully distinguish between the two charges: both charges were discussed in tandem without distinguishing between their distinct requirements (distinct elements of the crime). The Court acknowledges in its sentencing decision that "some of the facts overlap" between the charges, ${ }^{270}$ though, again, "some" is arguably minimizing the similarities: it is easy to find the overlap, the question is whether the Court, on the facts found, could find some if any differences (lack of overlap). ${ }^{271}$

At least overtly, the Court in Namouh did not explicitly note the differences it saw between conduct that led to two different counts. Indeed, the Court wrote that, "the only issue in dispute regarding counts 2 and 3 [under sections 83.18 and 83.19] is whether the GIMF is a terrorist group within the meaning of the Act"; 272 however, section 83.19 does not even refer to the definition of "terrorist group," making this issue hard to square with a finding under section 83.19 unless it was being conflated with the legal analysis of section 83.18.

In sum, the courts in both Khawaja and Namouh imposed consecutive sentences for each conviction under sections 83.18 and 83.19, despite the fact that both judgments acknowledged the high degree of overlap (or complete in the case of Namouh) between the charges while largely failing to distinguish meaningfully between the elements of the offences. The problem here is not merely that the more serious offence - facilitation - has seemingly been read down in the above-mentioned cases to what the court has explicitly called a "basket charge" that overlaps with a less serious offence. The problem is also that this judicial reasoning runs into a violation of the "Kienapple principle," that being that res

267 Ibid.

$268 \quad R v$ Khawaja, 2009 CanLII 100210 (Ont Sup Ct J) at para 54 [Khawaja Sentencing].

$269 \quad$ Namouh Trial, supra note 75 at paras 3,8 .

270 Namouh Sentencing, supra note 60 at para 101. The relevant sentence reads:

Section $83.26 \mathrm{Cr}$. C. contemplates consecutive sentences for counts 2 , 3, and 4 , even if some of the facts overlap. The sentence suggested by the prosecution for these counts totals twenty-six years. The Court finds that a four-year sentence on count 2 [83.18] and an eight-year sentence on each of counts 3 [83.19] and 4 would be sufficient, adding up to an overall sentence of twenty years for these three counts.

271 Not only does the Court analyze the two together on the same factual footing, but at various times it describes the elements of the offence for sections 83.18 and 83.19 as being exactly the same: "Under s. $83.18 \mathrm{Cr}$. C., it is sufficient for the accused to have facilitated terrorist activity with the intention of enhancing the ability of the group to carry out terrorist activity or to facilitate such activity. As for the offence under s. $83.19 \mathrm{Cr}$. C., it is sufficient for the accused to have knowingly facilitated terrorist activity": Namouh Trial, supra note 75 at para 68. 
judicata applies to prevent an individual from being convicted on multiple counts (offences) for the same conduct. ${ }^{273}$

An example might best explain the Kienapple principle. Max and Jonny get into a dispute and go outside to settle it. On his way out the door Max retrieves a large umbrella placed next to the door. When outside, Max uses his fencing training and the umbrella to "settle" the fight. Unbeknownst to Max, Jonny has a "thin skull" and dies from the one and only head shot inflicted by Max's umbrella. Max is charged with manslaughter under section 232 of the Criminal Code and in the alternative with aggravated assault under section 268 of the Criminal Code. But it is well known that if Max is found guilty at trial for manslaughter responsible for the death - he will not also be guilty of the assault, although he has clearly committed that offence as well. ${ }^{274}$ Instead, the Kienapple principle will apply and the individual will be charged with both offences but convicted only of the more serious (manslaughter) offence. The same factual elements underlining the commission of both criminal wrongs preclude the court from convicting an individual of multiple counts, all of which are based on precisely the same factual elements.

Oddly, the Court in Namouh seemed to recognize the possibility of a problem with sentencing for multiple offences on the same facts, and indeed did so - very briefly under the title of res judicata, without mentioning the well-worn Kienapple principle. ${ }^{275}$ In particular, the Court in Namouh adverted to the issue of res judicata, without proffering precisely what the problem was. Instead, under the heading of res judicata, discussed in the judgment without introduction, the Court noted that section 83.26 of the Criminal Code provides for the possibility of consecutive sentences for terrorism offences (as opposed to concurrent sentences). ${ }^{276}$ The Court reasoned that its simple, plain-word analysis of section 83.26 resolved the issue of whether it was possible to find the accused guilty on all counts because clearly the Criminal Code contemplated consecutive sentences in most terrorism cases.

But the reasoning, while admittedly sparse and thus hard to judge in full, is nevertheless surely flawed. Res judicata is not a principle that applies to sentencing, which is the proper application of section 83.26 of the Criminal Code. One does not relate to the other. Section 83.26 does nothing to displace the Kienapple principle, which deals with whether someone should be convicted of multiple offences based on the same factual elements. Consider the following. Section 83.26 is a sentencing provision applied at sentencing after a determination

Kienapple, supra note 150. In the words of the Supreme Court at 751: "If there is a verdict of guilty on the first count and the same or substantially the same elements make up the offence charged in a second count, the situation invites application of a rule against multiple convictions."

274 Indeed, under section 222(1)(a) of the Criminal Code, the Court will likely use the assault as the unlawful act to justify the manslaughter conviction.

275 Namouh was convicted on four counts: sections 83.18, 83.19, 83.2, 431.2(2). His sentences on sections 83.2, 83.18, and 83.19 were ordered served consecutively to each other but concurrently to the life sentence on section 431(2). See Namouh Trial, supra note 75 at paras 146-47; Namouh Sentencing, supra note 60 at para 101 .

276

\section{See Criminal Code, supra note 2, s 83.26 where it states:}

A sentence, other than one of life imprisonment, imposed on a person for an offence under any of sections 83.02 to 83.04 and 83.18 to 83.23 shall be served consecutively to

(a) any other punishment imposed on the person, other than a sentence of life imprisonment, for an offence arising out of the same event or series of events; and

(b) any other sentence, other than one of life imprisonment, to which the person is subject at the time the sentence is imposed on the person for an offence under any of those sections. 
of guilt and conviction on any charge is made and so, section 83.26 applies after Kienapple would be invoked. As the Supreme Court said in Kienapple: "the term res judicata best expresses the theory of precluding multiple convictions for the same delict, although the matter is the basis of two separate offences." ${ }^{277}$ If two counts largely cover the same delict, there should be no conviction on the second count - and thus no sentencing considerations. Put yet another way, section 83.26 states that if found guilty of multiple offences then the individual can be subject to consecutive rather than concurrent sentences; section 83.26 does not resolve the former question, that being if the accused could be convicted on multiple counts.

The Ontario Superior Court of Justice in Ahmed similarly averred to the Kienapple problem we have identified, though equally without recognizing it as such:

\begin{abstract}
As stated, while the legal requirements of each count are different, the factual foundation for each count was exactly the same. The maximum sentence for conspiracy [to facilitate] is 14 years. The maximum sentence for participating in terrorist activity is 10 years. In my view, where the same factual foundation forms the basis of liability on each count it would be an error in principle, not to mention manifestly unfair to the person convicted, to render a sentence that effectively punishes the offender twice for the same conduct. That, in effect, is what Crown counsel is urging me to do. ${ }^{278}$
\end{abstract}

However, the Court in Ahmed then treated the problem as one related to the "totality principle," which like section 83.26 is a sentencing principle and not one of res judicata. ${ }^{279}$ The totality principle demands that the entirety of the sentence be proportionate to the actions of the accused where an accused is sentenced on multiple, consecutive counts, just as section 83.26 informs the totality principle by requiring that convictions on multiple counts must be dealt with consecutively. Again, the Kienapple principle deals with whether multiple convictions should be entered in the first place and as such does not apply at the sentencing stage in the way that section 83.26 (Namouh) or the totality principle (Ahmed) does. ${ }^{280}$

This error was perpetuated in Ahmed at the Ontario Court of Appeal, where the Court found: "while the legal requirements of each count were different, the factual foundation was 'exactly the same'.... He concluded the sentence of 20 years sought by the Crown would effectively punish the offender twice for the same conduct and would 'constitute an inappropriate punishment.",281

As a result, just as in Namouh, Ahmed was convicted on both the facilitation and participation offences, a ruling that was upheld on appeal: "The decision of the court is that Mr. Ahmed will be sentenced to a term in penitentiary of 12 years, 5 years for conspiracy and 7 years consecutive for participating in the activities of a terrorist group. $" 282$ totality principle. It states: "where consecutive sentences are imposed, the combined sentence should not be unduly long or harsh." 
Note that the 12-year term for Ahmed could have been achieved - and surely justified simply by proper application of the Kienapple principle. In disposition, the lesser participation (section 83.18) count should have been dropped as per the Kienapple principle because it was premised on the very facts and delict as the facilitation offence, while at sentencing Ahmed could have been given 12 years for facilitation (which carries a 14-year maximum). The result is the same, but the legal explanation is very much different. In the latter case, the sentence is premised on the proper exercise of discretion by the sentencing judge; in the former case the Court achieves (arguably) a fair sentence through flawed reasoning, and in so doing both upends how sections 83.18 and 83.19 are to be analyzed and distinguished and how sentencing is to work when two terrorism charges are brought based on precisely the same factual elements.

The Crown does have a counter-argument here, though the courts have not yet meaningfully considered the alternatives and rendered a decision. ${ }^{283}$ That is, the Supreme Court in R. v. Prince made clear that: "It has been a consistent theme in the jurisprudence from Quon, through Kienapple and Krug that the rule against multiple convictions in respect of the same cause, matter or delict is subject to an expression of Parliamentary intent that more than one conviction be entered when offences overlap." 284 The Crown would then rely on the wording of section 83.26, as the courts have done above, but focus explicitly on the following: "A sentence ... shall be served consecutively to (a) any other punishment imposed on the person ... for an offence arising out of the same event or series of events." 285 The Crown would then argue that section 83.26 explicitly contemplates multiple convictions and consecutive sentences for multiple counts "arising out of the same events or series of events." 286

But this argument has two drawbacks. First, the displacement of Kienapple is not explicit in that, again, the wording of section 83.26 speaks to sentencing, which is a consideration after Kienapple is dealt with. Put another way, section 83.26 could just as easily be read to state that Kienapple continues to apply to terrorism sentences and, should the accused be convicted of two or more offences that both resulted from one "series of events" (say a twoyear bomb plot), then the accused shall be sentenced consecutively. The real intent of section 83.26, seen in this light, is that sentences "shall" (mandatory language) be consecutive; the judge's discretion to provide for concurrent sentences is displaced; the Kienapple principle is not. Second, there is a difference between saying someone shall be sentenced consecutively (or even convicted) of multiple offences that arise out of one long terrorist plot

The Ontario Superior Court of Justice did consider a res judicata application invoking Kienapple brought by Ali Dirie: Dirie, supra note 37. But the reasoning in this case does not address the overlap between sections 83.18 and 83.19 , either directly or indirectly. In Dirie, defence counsel submitted that the Crown had run afoul of the Kienapple principle by charging Dirie under section 83.2 with the predicate offence being Dirie's previous conviction under section 103(2) from two years before. In rejecting defence counsel's argument, the Court held that the Kienapple principle was of no application because the charges attached to different delicts (namely, section 83.2 attached to the benefit to a terrorist group that resulted from Dirie importing firearms illegally). Since the claim is that sections 83.18 and 83.19 can attach to exactly the same delict, the reasoning in Dirie is unhelpful here.

Criminal Code, supra note 2, s 83.26 [emphasis added].

Unfortunately for the Crown, the 2001 deliberations of the ATA being rushed as they were, that would seem the only explicit statement that might speak Parliamentary intent to displace Kienapple upon which they might rely. 
and saying that convictions should be entered for multiple counts the factual basis of which are indistinguishable.

For the accused, the problem is not merely theoretical. In Namouh, the Court cites the exact same set of facts to justify the sentences for both sections 83.18 and 83.19 without noting the overlap. For an accused and his family, this looks like "double punishment" and an unfair sentence, even if the sentence might have been the same had Kienapple been applied. ${ }^{287}$ Indeed, the Court in the Nuttall directed verdict motion raised this risk with respect to section 83.19 and section 83.2 (commission of an offence for a terrorist group), writing that a "broad interpretation of s. 83.19 builds in the spectre of double punishment for every act even remotely connected with a terrorist activity for the principal offender." ${ }^{288}$ As we have seen, so far the courts have been inclined to give section 83.19 just such a broad interpretation - by interpreting "knowingly" to exclude knowing the specifics of the plot for which the individual is accused of facilitating. Moreover, they have noted that section 83.19 can act as a "basket charge," or as the Court of Appeal in Ahmed said, that sections 83.18 and 83.19 can apply to factual conduct that is "exactly the same." ${ }^{289}$ To repeat the words of the Court in Ahmed, surely "where the same factual foundation forms the basis of liability on each count it would be an error in principle, not to mention manifestly unfair to the person convicted, to render a sentence that effectively punishes the offender twice for the same conduct." ${ }^{290}$

As a result, the unfair "double punishment" noted by the Court in Nuttall appears to have already come to pass in at least several terrorism cases to date. More than that, it is at risk of happening again unless either the Kienapple principle is properly applied or, ideally, it is applied and the courts begin to better differentiate between the overlapping terrorism offences, including at least some of the terrorist financing offences (particularly the broad section 83.03, discussed above) and the broad interpretation given to facilitation under section 83.19.

See Namouh Sentencing, supra note 60. Namouh was given a 12-year combined sentence. However, the Court could have simply sentenced him to $12-14$ years for the facilitation. So, again, it is less the outcome than the justification therefore. Having said this, there is no telling whether, had Kienapple been properly applied, the facilitation offence alone would have run shorter than the ultimate 12 -year sentence given to Namouh.

$288 \quad$ Nuttall Directed Verdict, supra note 238 at para 93.

289 Khawaja ONSC, supra note 12 at para 138; Ahmed Sentencing, supra note 11 at para 108. 
12. COMMISSION OF AN OFFENCE FOR A

TERRORIST GROUP (SECTION 83.2)

a. Judicial Consideration

\begin{tabular}{|c|c|c|c|}
\hline \multirow[b]{2}{*}{83.2} & \multicolumn{2}{|c|}{ Individuals charged under 83.2: } & Trial judgments: \\
\hline & $\begin{array}{l}\text { Shareef Abdelhaleem } \\
\text { Fahim Ahmad } \\
\text { Misbahuddin Ahmed } \\
\text { Ayanle Hassan Ali } \\
\text { Hiva Alizadeh } \\
\text { Zakaria Amara } \\
\text { Steven Chand } \\
\text { Mouna Diab } \\
\text { Sabrine Djermane } \\
\text { Chiheb Esseghaier } \\
\text { Saad Gaya } \\
\text { Othman Hamdan } \\
\text { Qayyum Jamal }\end{array}$ & $\begin{array}{l}\text { El Mahdi Jamali } \\
\text { Raed Jaser } \\
\text { Saad Khalid } \\
\text { Momin Khawaja } \\
\text { Amanda Korody } \\
\text { Carlos Larmond } \\
\text { Quebec Youth (LSJPA) } \\
\text { Manitoba Youth } \\
\text { Saïd Namouh } \\
\text { John Nuttall }\end{array}$ & $\begin{array}{l}\text { R. v. Ayanle Hassan Ali, } 2018 \\
\text { ONSC } 2838 \\
\text { R. v. Nuttall, } 2015 \text { BCSC } 961 \\
\text { R. v. Nuttall, } 2015 \text { BCSC } 943 \\
\text { R. v. Hamdan, } 2017 \text { BCSC } 1770 \\
\text { R. v. Khawaja, } 2008 \text { CanLII } 92005 \text { (Ont } \\
\text { Sup Ct J) } \\
\text { R. v. Khawaja, } 2012 \text { SCC } 69 \\
\text { R. v. Ahmad, } 2009 \text { CanLII } 84774 \text { (Ont } \\
\text { Sup Ct J) }\end{array}$ \\
\hline
\end{tabular}

\section{b. Criminal Code Provision}

Commission of offence for terrorist group

83.2 Every one who commits an indictable offence under this or any other Act of Parliament for the benefit of, at the direction of or in association with a terrorist group is guilty of an indictable offence and liable to imprisonment for life. ${ }^{291}$

Section 83.2 takes every indictable offence in the Criminal Code and then creates a greater offence for each one by adding on a further "essential element; namely, that the existing Criminal Code offence was committed for the benefit of, at the direction of, or in association with a terrorist group." ${ }^{292}$ The British Columbia Supreme Court in Nuttall characterized this offence as being the appropriate charge where the accused participated in terrorist activity as a "principal actor and not merely as a peripheral supplier of services and skills." 293 In other words, section 83.2 is reserved for the most serious terrorism offenders, in practice those central to the organization and planning of the terrorist plot.

The British Columbia Supreme Court noted in Hamdan that the actus reus of an offence under section 83.2 is simply the actus reus of the underlying offence plus the additional element from 83.2, that is, that the offence was committed "for the benefit of, at the direction of or in association with a terrorist group." ${ }^{294}$ Of course, this is where the previous discussion of section 83.2's application to lone wolf actors becomes relevant. If the Court's judgment 
in Ali is followed, "for the benefit of, at the direction of or in association with a terrorist group" will be defined to exclude lone wolf actors. If the judgment is overturned on appeal, such that any one person who otherwise commits a crime on behalf of anyone who holds a terrorist purpose - anyone, including himself, who otherwise meets the definition of terrorist activity - then lone wolves will be covered by section 83.2 going forward. Of course, if the former definition is maintained then courts will have interpreted section 83.2 in such a way that terrorist activity is not a terrorism offence so long as it is committed by a lone wolf, something that Parliament may intervene to correct.

Moreover, on a plain reading, section 83.2 otherwise does not add any specific mens rea component beyond that of the underlying offence. ${ }^{295}$ As such, Roach has suggested that in order for section 83.2 to meet the constitutional minimum subjective fault requirement, judges will have to read in a requirement that the accused knew he was benefitting a terrorist group, or acting at its direction or in association with it. ${ }^{296}$ The Court in Hamdan suggested that the Supreme Court's reasoning in Khawaja applies equally to section 83.2. That is, the reasons for importing an ulterior motive requirement into section 83.18 could equally justify importing a knowledge requirement into section 83.2. ${ }^{297}$ The Court also echoed Roach's recommendation, that the lengthy sentence and severe stigma attached to the offence warrant reading in a higher fault requirement that the accused intended "to benefit, follow the direction or act in association with a terrorist group." 298

Roach's position is also supported by the trial judge's finding in Khawaja: although Khawaja was guilty of the underlying explosives offenses, the terrorist cell had kept him in the dark regarding the fertilizer bomb plot in London - the focus of the indictment. ${ }^{299}$ The evidence did not establish that Khawaja knew of the fertilizer bomb plot, and therefore, the Crown had not made out the mens rea of section 83.2. ${ }^{300}$ The issue of whether or not courts will read in a specific intent requirement in the future should be of keen interest to defence counsel, particularly considering that the Court in Hamdan expressly "highlight[ed] it ... for future consideration." 301

\section{Instructing to Carry Out Terrorist Activity (Section 83.22)}

a. Judicial Consideration

\begin{tabular}{|l|l|l|}
\hline $\mathbf{8 3 . 2 2}$ & $\begin{array}{l}\text { Individuals charged under } \\
\mathbf{8 3 . 2 2}:\end{array}$ & Trial judgments: \\
\cline { 2 - 3 } & Othman Hamdan & R. v. Hamdan, 2017 BCSC 1770 \\
\hline
\end{tabular}


b. Criminal Code Provision

Instructing to carry out terrorist activity

83.22 (1) Every person who knowingly instructs, directly or indirectly, any person to carry out a terrorist activity is guilty of an indictable offence and liable to imprisonment for life.

Prosecution

(2) An offence may be committed under subsection (1) whether or not

(a) the terrorist activity is actually carried out;

(b) the accused instructs a particular person to carry out the terrorist activity;

(c) the accused knows the identity of the person whom the accused instructs to carry out the terrorist activity; or

(d) the person whom the accused instructs to carry out the terrorist activity knows that it is a terrorist activity. $^{302}$

Section 83.22 applies to every person who knowingly (mens rea) instructs, directly or indirectly, any person to carry out a terrorist activity (actus reus) ${ }^{303}$ To date, the only person to be charged under this provision was Othman Ayed Hamdan, who stood accused of making numerous Facebook posts sympathetic to the cause of the Islamic State and allegedly calling for "lone wolf" attacks. As already noted, a pre-trial ruling resulted in the exclusion of many of the impugned posts from evidence, ${ }^{304}$ and Hamdan was ultimately acquitted on all counts. ${ }^{305}$ However, the Court did briefly summarize the elements of the section 83.22 instructing offence. ${ }^{306}$

The Court in Hamdan held that the actus reus of this offence requires the Crown to prove that the accused instructed a person to carry out a terrorist activity, which is at least as onerous as the actus reus for counselling another offence under section 464 of the Criminal Code ("deliberately encouraged" or "actively induced"). ${ }^{307}$

Interestingly, the Court in Hamdan noted that the mens rea of section 83.22 runs into the same issue as we saw earlier with section 83.2 because the provision itself does not clearly provide for a specific knowledge requirement. Therefore, the same comments apply mutatis mutandis here as they did under the section 83.2 discussion, that being that a judge in a future trial may have to read in a mens rea requirement that the accused knew he was instructing a terrorist activity, as opposed to knowingly instructing an activity that then happened to be terrorist. Again, an accused would not need to know the legal definition of "terrorist activity"

\footnotetext{
302 Criminal Code, supra note 2, s 83.22.

303 Ibid.

$304 \quad$ Hamdan Trial, supra note 11.

$305 \quad$ Ibid at para 195

306 Ibid at paras 191-95. The Court's analysis of the instructing offence under section 83.22 was brief because the Crown had failed to prove the first three counts, and Crown counsel had conceded earlier in the proceedings that a failure to prove the first three counts would also result in a failure to prove the fourth count: ibid at paras 61,192 . Ibid at para 192 .
} 
in order to have the requisite mens rea; he must simply have knowledge of the facts that would bring the activity to be instructed within the definition of "terrorist activity." 308

\section{CONCluSions \\ AND FUTURE CONSIDERATIONS}

The first 17 years of prosecutions under the Part II.1 Criminal Code terrorism offences have resolved a number of controversies, but they have also raised new questions. Both of the two major initial concerns about the Criminal Code's Part II.1 terrorism regime have been settled by the Supreme Court of Canada, that is, whether the motive clause violates religious or expressive freedoms, ${ }^{309}$ and whether the participation offence (section 83.18) was too far removed from a substantive offence to justify criminal liability such that it was an "inchoate upon inchoate" offence. ${ }^{310}$

However, the courts have both broadly interpreted the section 83.19 facilitation offence and failed repeatedly to adequately distinguish it from other terrorism offences, particularly the section 83.18 participation offence, raising questions about what distinguishes facilitation from the other commonly charged provisions. While only three accused have been charged and convicted under sections 83.18 and 83.19 , the spectre of double punishment was raised in all three cases due to a failure to distinguish a unique delict for each provision. Moreover, as discussed above, with respect to the actus reus, the extended definition of "facilitation" in section 83.19(2) may raise the "inchoate upon inchoate" issue again; and with respect to the mens rea, the extended definition of facilitation, in the words of Roach, "goes beyond watering down the fault element to obliterating it," as it seems impossible to knowingly facilitate a terrorist activity "when you do not know that "any particular terrorist activity was foreseen or planned at the time it was facilitated." 311 Further, the issue of whether courts will read in a specific mens rea for section 83.2 (commission of an offence for a terrorist group) or section 83.22 should be of keen interest to defence counsel, particularly considering that the Court in Hamdan expressly "highlight[ed] it ... for future consideration." 312

Finally, we have seen that the terrorism financing sections are, in theory, broad enough to cover most or all conceivable forms of terrorist financing. But, as with sections 83.18 and 83.19 , there is no clear differentiation between the ultimate scope of the discrete terrorist financing provisions. Section 83.03's expansive actus reus ("making available" property or financial services) in particular may create another Kienapple problem should it ever be charged in conjunction with sections 83.02 and 83.04. Section 83.03(b) could also face additional scrutiny given it is possible to be convicted under it for financing a terrorist group that is also a "listed entity" without the Crown offering evidence of the group's terrorist activity.

\footnotetext{
308 Hamdan Trial, supra note 11 at para 188

$309 \quad$ Khawaja SCC, supra note 76 at para 85.

310 Ibid at paras 51-53; Ansari ONCA, supra note 177 at para 178; Ahmad Constitutional Challenge, supra note 78 at para 44; Hersi Constitutional Challenge, supra note 78 at paras 24, 30, 35-36, 41.

311 Roach, "Canada's New Anti-Terrorism Law," supra note 95 at 138.

312 Hamdan Trial, supra note 11 at para 190
} 
In the future, it will be interesting to watch interpretations of these provisions mature, and to see how interpretations of these terrorism offences will evolve and adapt to capture the evolving terrorist threat. For now, we can say that the Criminal Code's Part II.1 terrorism offences have not been "impossible" to prove, though they have raised a host of complex questions for the courts due to the overlap that would seem to exist between the offences as drafted. In some ways, this has meant that the offences are just the opposite of impossible to prove. Certainly terrorism offences remain extremely challenging from an evidential and investigative perspective. But once the charges get to court, the judiciary has been loath to overturn as unconstitutional overbroad drafting, choosing instead to read it down; it has provided elusive distinctions between the elements of various offences leading to convictions for multiple offences for what seem to be the same actions (and the description of section 83.19 as a basket charge). Whether this judicial practice continues, or whether the courts begin to get stricter with the elements of the various terrorism offences as everyone becomes more accustomed to them, will be very interesting to follow in the years ahead. 